\title{
Universiteit
}

Leiden

The Netherlands

\section{Rollover cyclometalation vs nitrogen coordination in Tetrapyridyl Anticancer Gold(III) complexes: effect on protein interaction and toxicity}

Zhou, X.; Carbo-Bague, I.; Siegler, M.A.; Hilgendorf, J.; Basu, U.; Ott, I.; ... ; Bonnet, S.A.

\section{Citation}

Zhou, X., Carbo-Bague, I., Siegler, M. A., Hilgendorf, J., Basu, U., Ott, I., ... Bonnet, S. A. (2021). Rollover cyclometalation vs nitrogen coordination in Tetrapyridyl Anticancer Gold(III) complexes: effect on protein interaction and toxicity. Jacs $A u, 1(4), 380-395$.

doi:10.1021/jacsau.0c00104

Version: $\quad$ Publisher's Version

License: $\quad$ Creative Commons CC BY-NC-ND 4.0 license

Downloaded from: https://hdl.handle.net/1887/3275672

Note: To cite this publication please use the final published version (if applicable). 


\section{Rollover Cyclometalation vs Nitrogen Coordination in Tetrapyridyl Anticancer Gold(III) Complexes: Effect on Protein Interaction and Toxicity}

Xue-Quan Zhou, Imma Carbo-Bague, Maxime A. Siegler, Jonathan Hilgendorf, Uttara Basu, Ingo Ott, Rongfang Liu, Liyan Zhang, Vadde Ramu, Adriaan P. IJzerman, and Sylvestre Bonnet*

Cite This: JACS Au 2021, 1, 380-395

Read Online

ABSTRACT: In this work, a pair of gold(III) complexes derived from the analogous tetrapyridyl ligands $\mathrm{H}_{2}$ biqbpyl and $\mathrm{H}_{2}$ biqbpy 2 was prepared: the rollover, bis-cyclometalated $[\mathrm{Au}($ biqbpyl $) \mathrm{Cl}([1] \mathrm{Cl})$ and its isomer $[\mathrm{Au}-$ (biqbpy2) $\mathrm{Cl}([2] \mathrm{Cl})$. In $[1]^{+}$, two pyridyl rings coordinate to the metal via a $\mathrm{Au}-\mathrm{C}$ bond $\left(\mathrm{C}^{\wedge} \mathrm{N}^{\wedge} \mathrm{N}^{\wedge} \mathrm{C}\right.$ coordination) and the two noncoordinated amine bridges of the ligand remain protonated, while in $[2]^{+}$all four pyridyl rings of the ligand coordinate to the metal via a $\mathrm{Au}-\mathrm{N}$ bond $\left(\mathrm{N}^{\wedge} \mathrm{N}^{\wedge} \mathrm{N}^{\wedge} \mathrm{N}\right.$ coordination), but both amine bridges are deprotonated. As a result, both complexes are monocationic, which allowed comparison of the sole effect of cyclometalation on the chemistry, protein interaction, and anticancer properties of the gold(III) compounds. Due to their identical monocationic charge and similar molecular shape, both complexes $[1] \mathrm{Cl}$ and $[2] \mathrm{Cl}$ displaced reference radioligand $\left[{ }^{3} \mathrm{H}\right]$ dofetilide equally well from cell membranes expressing the

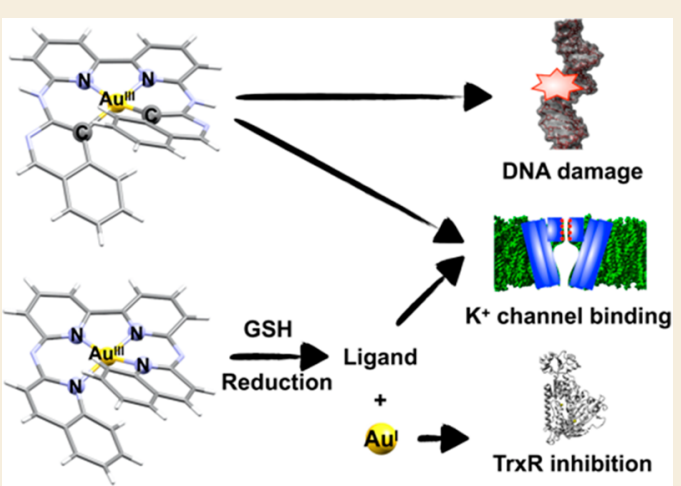
$\mathrm{K}_{\mathrm{v}} 11.1$ (hERG) potassium channel, and more so than the tetrapyridyl ligands $\mathrm{H}_{2}$ biqbpy1 and $\mathrm{H}_{2}$ biqbpy2. By contrast, cyclometalation rendered $[1] \mathrm{Cl}$ coordinatively stable in the presence of biological thiols, while [2] $\mathrm{Cl}$ was reduced by a millimolar concentration of glutathione into metastable $\mathrm{Au}(\mathrm{I})$ species releasing the free ligand $\mathrm{H}_{2}$ biqbpy2 and TrxR-inhibiting Au ions. The redox stability of [1] Cl dramatically decreased its thioredoxin reductase (TrxR) inhibition properties, compared to [2]Cl. On the other hand, unlike [2] Cl, [1] Cl aggregated into nanoparticles in FCS-containing medium, which resulted in much more efficient gold cellular uptake. [1] Cl had much more selective anticancer properties than [2] $\mathrm{Cl}$ and cisplatin, as it was almost 10 times more cytotoxic to human cancer cells (A549, A431, A375, and MCF7) than to noncancerous cells (MRC5). Mechanistic studies highlight the strikingly different mode of action of the two compounds: while for [1] Cl high gold cellular uptake, nuclear DNA damage, and interaction with hERG may contribute to cell killing, for [2] $\mathrm{Cl}$ extracellular reduction released TrxR-inhibiting Au ${ }^{+}$ions that were taken up in minute amounts in the cytosol, and a toxic tetrapyridyl ligand also capable of binding to hERG. These results demonstrate that bis-cyclometalation is an appealing method to improve the redox stability of Au(III) compounds and to develop gold-based cytotoxic compounds that do not rely on TrxR inhibition to kill cancer cells.

KEYWORDS: Organometallic, polypyridyl, cancer, metallodrugs, cyclometalation, gold, thiol, nitrogen ligands

\section{INTRODUCTION}

The discovery of cisplatin's anticancer activity has brought a new era for the bioinorganic and medicinal chemistry communities. ${ }^{1}$ Nowadays, cisplatin is one of the main chemotherapeutic drugs for the treatment of various cancers. However, the corresponding trans isomer, trans- $\left[\mathrm{Pt}\left(\mathrm{NH}_{3}\right)_{2} \mathrm{Cl}_{2}\right]$, is clinically inefficient, which is attributed to its much lower efficiency to form crosslinked DNA adducts. ${ }^{2}$ Overall, the anticancer properties of a metal compound can be strongly influenced by the intrinsic (stereo)chemical differences between two isomers. ${ }^{3}$ Recently, establishing a structure-activity relationship between isomers of the same molecule has emerged as a new frontier in bioinorganic medicinal chemistry. ${ }^{4,5}$
Next to platinum itself, many heavy metal complexes are being investigated for their potential anticancer properties. They may show different modes of action (MOA), such as DNA binding, disruption of membranes, enzyme inhibition, or reactive oxygen species generation, which allows them in many cases to overcome the resistance of tumors to cisplatin..$^{6-9}$ In particular, gold complexes have been considered as an alternative to

Received: December 9, 2020

Published: March 16, 2021 
Scheme $1^{a}$

a)<smiles></smiles><smiles>CCCCCCCC</smiles><smiles></smiles><smiles>C1CCCCC1</smiles><smiles></smiles><smiles>[B][B-]</smiles><smiles>Cn1c2cccnc2c2cccn21</smiles>

b)<smiles>c1ccc2cc(Nc3cc4ccccc4cn3)ncc2c1</smiles>

$\mathrm{H}_{2}$ biqbpy1<smiles></smiles>

$\mathrm{H}_{2}$ biqbpy2

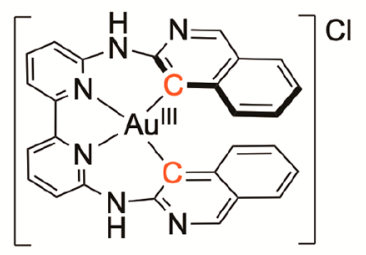

[1]Cl

(ii) $\mathrm{Cl}^{-}$ion exchange

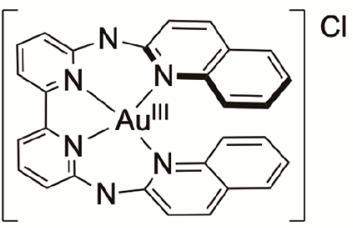

[2]Cl

a (a) Scheme for rollover cyclometalation. Adapted from ref 40. Copyright 2015 American Chemical Society. "B" represents a base. (b) Synthesis of the gold complexes $[1] \mathrm{Cl}$ and $[2] \mathrm{Cl}$.

platinum because of the specific affinity of gold(I) ions for the thiol groups present in many biomolecules, ${ }^{10}$ especially thioredoxin reductase (TrxR) and glutathione (GSH). , $^{81-14}$ The TrxR/GSH system and its different components have been reported as the major cellular line of defense against increased oxidative stress and the accumulation of reactive oxygen species (ROS); when it works properly, it helps the cell to stay alive. Meanwhile, the expression of these two biomolecules is known to be higher in cancer cells than in normal cells, as the former need to sustain a higher metabolism than the latter do. ${ }^{15,16}$ Altogether, the TrxR/GSH system has been recognized as a good target for anticancer therapy, ${ }^{17,18}$ notably for gold prodrug candidates. ${ }^{14}$ For example, auranofin, a $\mathrm{Au}(\mathrm{I})$ compound characterized by the coordination of a phosphine and a thiol ligand in a linear arrangement, has been clinically approved for the treatment of rheumatoid arthritis for years. ${ }^{19}$ More recently, it has also been thoroughly investigated as an anticancer drug for its significant inhibition properties toward TrxR. ${ }^{20,21}$ Next to $\mathrm{Au}(\mathrm{I})$, many $\mathrm{Au}(\mathrm{III})$ compounds have been evaluated as anticancer drugs, ${ }^{22-32}$ with many of them based on polypyridyl ligands. Interestingly, polypyridyl $\mathrm{Au}(\mathrm{III})$ complexes are typically reduced to $\mathrm{Au}(\mathrm{I})$ species upon cellular uptake, which is often accompanied by the release of the polypyridyl ligand(s). ${ }^{12,23}$ Some $\mathrm{Au}(\mathrm{III})$ polypyridyl complexes are also reactive to the thiol residue of human serum albumin, ${ }^{33}$ which may lead to the dissociation of the complex before it reaches cancer tissues. By contrast, cyclometalated $\mathrm{Au}$ (III) complexes, i.e., compounds that have at least one metal-carbon $\sigma$ bond, have been considered because of their higher redox stability in physiological conditions. ${ }^{8,12}$ On the other hand, cyclometalation typically reduces the positive charge of a $\mathrm{Au}$ (III) complex, which can strongly modify its biological properties, notably its cellular uptake and/or interaction with serum proteins. ${ }^{34}$
Most cytotoxic, cyclometalated $\mathrm{Au}$ (III) complexes known to date are based on the combination of a bipyridine or terpyridine ligand and monodentate ligand(s), ${ }^{14,15}$ while cyclometalated $\mathrm{Au}(\mathrm{III})$ complexes based on tetradentate ligands are rare in a biological context. ${ }^{34-36}$ Among the different reactions available to prepare cyclometalated complexes, the unconventional method called "rollover" has been identified in recent years, in particular for catalyst design where noncoordinated nitrogen atoms generated by the rollover may provide additional catalytic activity. ${ }^{37}$ Rollover cyclometalation is a specific reversal of the coordination mode of a pyridyl moiety, from the expected metal-nitrogen bonding mode to a cyclometalated coordination mode where a meta $\mathrm{CH}$ group in the same heterocyclic ring is deprotonated to generate a metal-carbon bond (Scheme 1a). ${ }^{37}$ Rollover compounds have been predominantly described for bipyridine ligands coordinated to heavy atoms such as $\mathrm{Pt}$ (II) or $\operatorname{Ir}(\mathrm{III})^{37,38}$ and were extensively developed by the Zucca group. ${ }^{39,40}$ Recently, Hartinger et al. evaluated the anticancer abilities of a series of rollover cyclometalated bipyridine $\mathrm{Pt}$ (II) complexes, which appeared to be significantly influenced by the ancillary ligands. ${ }^{41}$ Though $\mathrm{Au}(\mathrm{III})$ is isoelectronic to $\mathrm{Pt}(\mathrm{II})$ and shares its ability to cyclometalate, the synthesis of rollover cyclometalated $\mathrm{Au}$ (III) complexes has been rarely reported, ${ }^{42-44}$ while the effects of rollover cyclometalation vs nitrogen coordination on the biological properties of analogous $\mathrm{Au}(\mathrm{III})$ complexes are, to our knowledge, unknown.

In this work, we studied the coordination of two isomers of a tetrapyridyl ligand, i.e., (N6,N6' - di(isoquinolin-3-yl)-[2,2' bipyridine $]-6,6^{\prime}$-diamine $\left(\mathrm{H}_{2}\right.$ biqbpyl) and N6,N6'-di(quinolin-2-yl)-[2,2'-bipyridine]-6,6'-diamine ( $\mathrm{H}_{2}$ biqbpy2), to $\mathrm{Au}(\mathrm{III})$ (Scheme $1 \mathrm{~b}$ ). Unexpectedly, in the same reaction conditions, the former ligand led to the formation of the rollover bis-cyclometalated monocationic $\mathrm{Au}(\mathrm{III})$ complex [1] Cl, while 
a

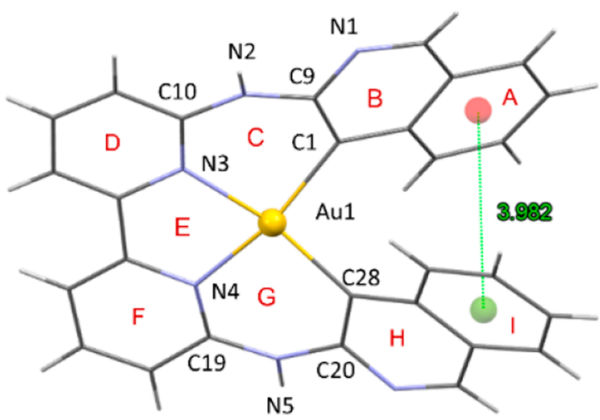

[1]CI

b

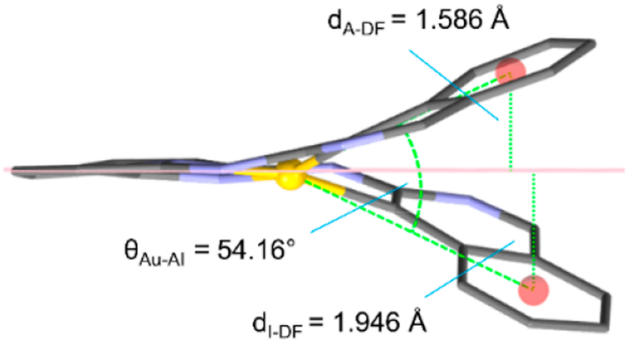

[1]Cl

c
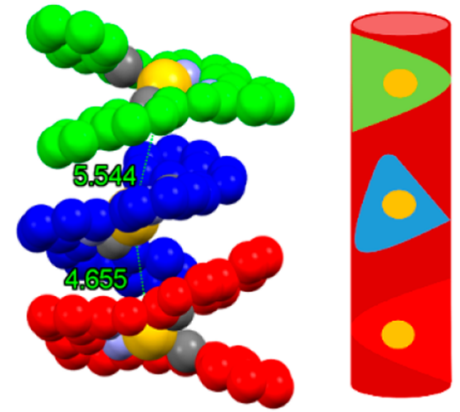

[1]CI

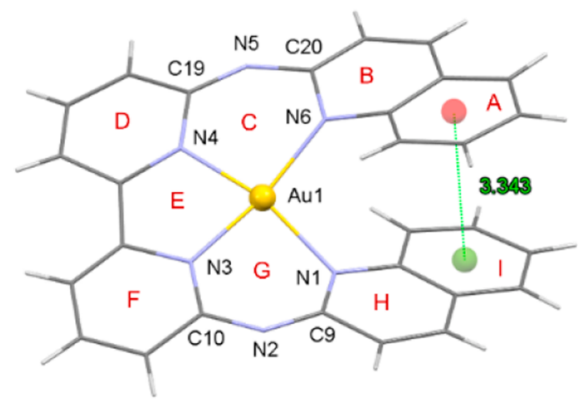

[2] $\left(\mathrm{AuCl}_{4}\right)$

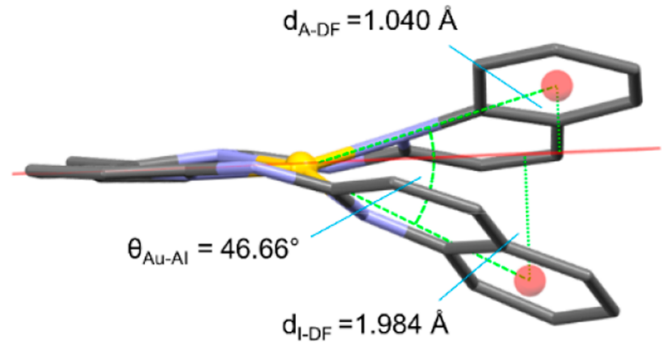

[2] $\left(\mathrm{AuCl}_{4}\right)$

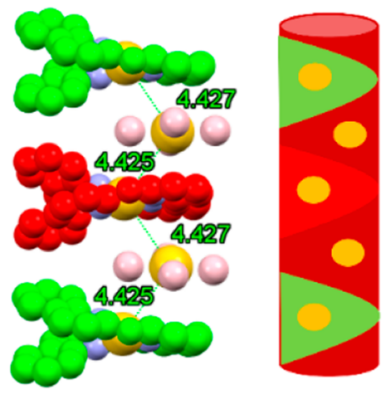

[2] $\left(\mathrm{AuCl}_{4}\right)$

Figure 1. (a) Cationic part and ring numbers (red characters) in the crystal structures (wireframe style) of gold complexes $[1] \mathrm{Cl}_{\text {and }}[2]\left(\mathrm{AuCl}_{4}\right)$. The counterions were omitted for clarity. (b) Selected angles $(\mathrm{deg})$ and distances $(\AA)$ in $[1] \mathrm{Cl}$ and $[2]\left(\mathrm{AuCl}_{4}\right)$. The least-squares plane defined by the rings $\mathrm{D}$ and $\mathrm{F}$ is shown as a red line. For $[1] \mathrm{Cl}$, only one of the three crystallographically independent cations is shown in (a) and (b). (c) Space fill construction and schematic pictures of the supramolecular helixes in the crystal structure of [1] Cl and [2] $\left(\mathrm{AuCl}_{4}\right)$. The Au atoms are labeled in yellow, $\mathrm{Cl}$ in pink, coordinated $\mathrm{N}$ in pale blue, coordinated $\mathrm{C}$ in gray, and noncoordinated $\mathrm{C}$ in green, dark blue, and red.

the latter led to the tetrapyridyl coordination isomer, [2] $\mathrm{Cl}$, which is characterized by deprotonated $\mathrm{NH}$ bridges and hence also bears a single positive charge. Both monocationic complexes were fully characterized, the reason for rollover was studied by DFT calculations, and the biological activities of the two compounds were compared. Our results demonstrate that rollover cyclometalation dramatically influenced the reactivity of the gold complex toward thiol groups, its interactions with proteins, and the selectivity of its cytotoxic properties toward cancer cells.

\section{RESULTS}

\section{Synthesis}

The ligands $\mathrm{H}_{2}$ biqbpyl and $\mathrm{H}_{2}$ biqbpy 2 were prepared according to the literature. ${ }^{45}$ Upon refluxing for 3 days under $\mathrm{N}_{2}$, with a mixture of each ligand with 1 equiv of $\mathrm{HAuCl}_{4}$ in methanol, the gold complexes $[\mathrm{Au}(\text { biqbpy } 1)]^{+}\left([1]^{+}\right)$and $[\mathrm{Au}(\text { biqbpy } 2)]^{+}$ $\left([2]^{+}\right)$were obtained after purification by silica column chromatography (Scheme 1b). The complexation of gold(III) to the ligands was confirmed via NMR. The ${ }^{1} \mathrm{H}$ NMR peak at $11.70 \mathrm{ppm}$ (400 $\left.\mathrm{MHz}, \mathrm{DMSO}-d_{6}\right)$ demonstrated the protonation of the two secondary amine bridges of the ligand in $[1]^{+}$. By contrast, similar high-chemical shift peaks were not observed for $[2]^{+}$, suggesting at least partial deprotonation of the amine bridges. Next to these differences, the 2D-NMR analysis also provided strong evidence that $[1]^{+}$and $[2]^{+}$were coordinated following a different pattern. The ${ }^{13} \mathrm{C}$-APT NMR showed that $[1]^{+}$had two quaternary carbon atoms more than $[2]^{+}$, indicating that $[1]^{+}$had two more $\mathrm{Au}-\mathrm{C}$ bonds. It should be noticed that at that stage ${ }^{1} \mathrm{H}$ NMR and ESI mass spectrometry did not yield insight in the nature of the counterion of these $\mathrm{Au}(\mathrm{III})$ complexes; probably, these samples had mixed counterions, i.e., $\mathrm{AuCl}_{4}{ }^{-}, \mathrm{AuCl}_{2}{ }^{-}$, and/or $\mathrm{Cl}^{-}$. ${ }^{46}$ Thus, a chloride-loaded 
a

$[\mathbf{1}]^{+}$

Structure

HOMO

LUMO
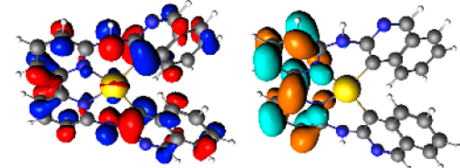

$[1 \mathrm{a}]^{+}$
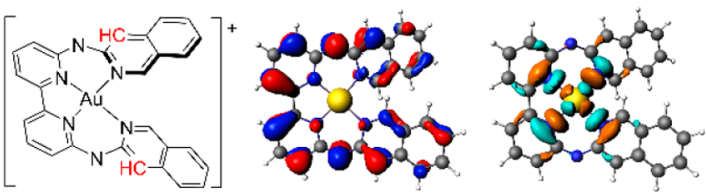

b

Structure

HOMO

LUMO

[2]
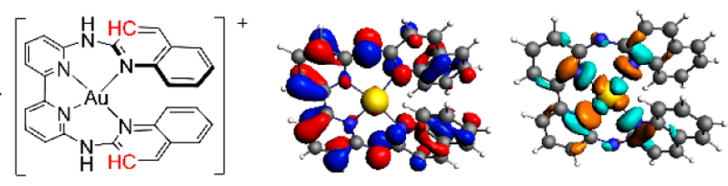

[2a] $]^{+}$
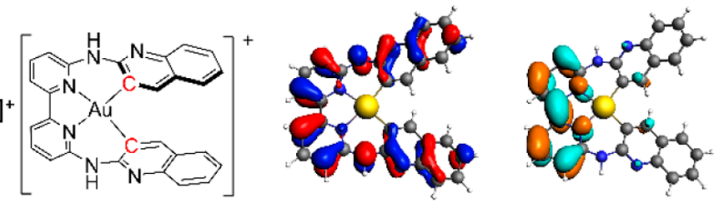

c
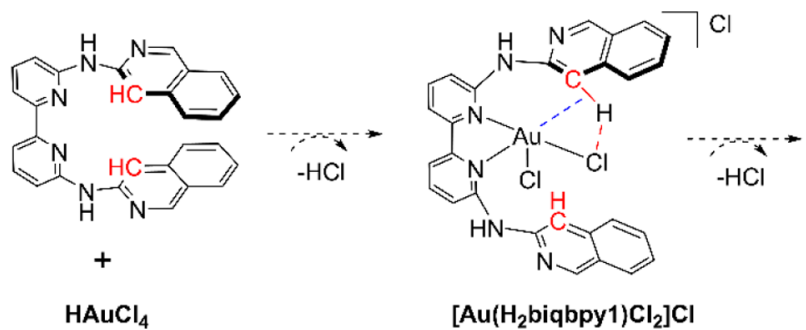

$\left[\mathrm{Au}\left(\mathrm{H}_{2}\right.\right.$ biqbpy 1$\left.) \mathrm{Cl}_{2}\right] \mathrm{Cl}$

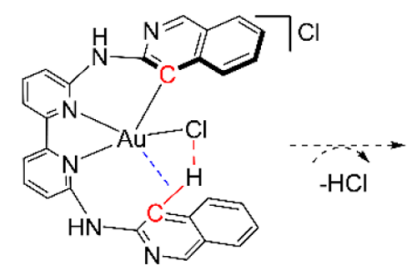

[Au(Hbiqbpy1) Cl]C

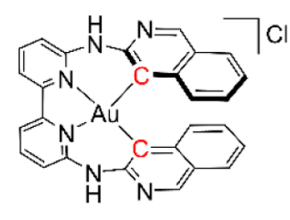

[1]CI

$\mathrm{H}_{2}$ biqbpy1 + $\mathrm{HAuCl}_{4}$

$[1] \mathrm{Cl}+3 \mathrm{HCl}$

Figure 2. Structure, calculated geometry, and frontier orbitals (HOMO, LUMO) of (a) $[1]^{+}$and $[1 \mathrm{a}]^{+}$, (b) $[2]^{+}$and $[2 \mathrm{a}]^{+}$. (c) Proposed mechanism for the $\mathrm{C}-\mathrm{H}$ activation and cyclometalation of $\mathrm{H}_{2}$ biqbpyl to form [1]Cl.

ion-exchange resin was used to better define the nature of the counteranion. Full characterization of the two compounds is given in the Supporting Information. The water/n-octanol $\log P_{\text {ow }}$ value and water solubility of $[1] \mathrm{Cl}$ and $[2] \mathrm{Cl}$ were measured via inductively coupled plasma mass spectrometry (ICP-MS, see Table S1). The $\log P_{\text {ow }}$ values were found to be close: +0.83 for $[1] \mathrm{Cl}$ and +0.35 for $[2] \mathrm{Cl}$, showing the higher lipophilicity of the cyclometalated analogue. This was confirmed by the significantly lower water solubilities of $[1] \mathrm{Cl}(0.0064 \mathrm{mg} /$ $\mathrm{mL})$, compared to $[2] \mathrm{Cl}$, that dissolves in water at concentrations up to $1.45 \mathrm{mg} / \mathrm{mL}$.

\section{X-ray Crystallography and Structure Determination}

Slow vapor diffusion of ethyl acetate into a methanol/DCM solution containing $[1]^{+}$or $[2]^{+}$gave red and black single crystals, respectively, suitable for $\mathrm{X}$-ray crystal structure determination. The crystallographic data and selected bond distances and angles are shown in Tables S2-S4. The two crystal structures are shown to contain different counteranions: one chloride anion per gold center for $[1]^{+}$, and one $\mathrm{AuCl}_{4}{ }^{-}$complex anion per cationic gold complex for $[2]^{+}$. The compound $[1] \mathrm{Cl}$ crystallized in the monoclinic $P 2_{1} / c$ space group, while $[2]\left(\mathrm{AuCl}_{4}\right)$ crystallized in the monoclinic $P 2_{1}$ space group. The cationic part of the two complexes showed a strikingly similar, helical molecular shape. The crystal structure of $[1]^{+}$ showed that it was a double "rollover" cyclometalated complex, characterized by a $\mathrm{C}^{\wedge} \mathrm{N}^{\wedge} \mathrm{N}^{\wedge} \mathrm{C}$ coordination mode (Figure 1a), while $[2]^{+}$was a classical tetrapyridyl complex, characterized by a $\mathrm{N}^{\wedge} \mathrm{N}^{\wedge} \mathrm{N}^{\wedge} \mathrm{N}$ coordination mode (Figure 1a). The $\mathrm{M}-\mathrm{C}$ bond distances in $[1]^{+}(2.030(7)-2.060(5) \AA)$ were similar to the $\mathrm{M}-\mathrm{N}$ bond distances in $[2]^{+}(1.995(18)-2.081(18))$. The two complexes exhibited distorted square-planar coordination spheres, as confirmed by the moderate tetradentate $\tau$ distortion values, i.e., $\tau=0.19$ for $[1] \mathrm{Cl}$ and $\tau=0.21$ for $[2]\left(\mathrm{AuCl}_{4}\right)(\tau=$ $[360-(\alpha+\beta)] / 141$, where $\alpha$ and $\beta$ are the two greatest coordination angles of the tetradentate coordination sphere; $\tau=$
0 reflects perfect planar coordination, and $\tau=1$ indicates perfect tetrahedral coordination). Besides showing different coordination spheres, the two complexes were also characterized by significant differences in the geometry of their amine bridges. Clearly, in $[1]^{+}$, the bond distances in the bridge C9-N2, N2C10, C19-N5 and N5-C20 fell within 1.348(10)-1.415(14) A, indicative of a single bond character for both $\mathrm{C}-\mathrm{NH}$ bonds. On the contrary, the amine-carbon bonds in $[2]^{+}$were shorter, 1.331(7) and 1.40(3) ^, suggesting a higher double bond character for both amine-carbon bonds $(\mathrm{C}=\mathrm{N}-\mathrm{C})$. This result suggested that the amine bridge in $[1]^{+}$was protonated while that in $[2]^{+}$was deprotonated, thus generating conjugation between the lone pairs on the nitrogen bridges with the $\pi$ system of the polypyridyl ligand. Last but not least, the highly distorted coordination sphere in both complexes generated a strongly helical structure, with both enantiomers being present as a 1:1 mixture in the crystal lattice because of the centrosymmetric space groups. In $[1]^{+}$, a quite similar helical structure, compared with $[2]^{+}$, was obtained due to the rollover cyclometalation. It was accompanied by a short centroidcentroid distance between rings $\mathrm{A}$ and $\mathrm{I}$ of the quinoline groups (Figure 1a, $3.982 \AA$ for $[1]^{+}, 3.343 \AA$ for $[2]^{+}$), which is close to the typical $\pi-\pi$ stacking distance of aromatic rings $(3.4 \AA),{ }^{47}$ indicative of intramolecular $\pi-\pi$ stacking between the two quinoline moieties in both complexes.

The prototypical molecular helixes, helicenes, are organic compounds. ${ }^{48,49}$ However, metal-based molecular helixes have also been described by Lehn, ${ }^{50,51}$ Sauvage, ${ }^{52,53}$ and Hannon, ${ }^{54-56}$ for example. In this work, the helical structures of the gold complexes $[1]^{+}$and $[2]^{+}$indicate that gold complexation can be a new strategy to develop helical systems from planar ligands. In $[1]^{+}$, the perpendicular distances between the centroids of the terminal ring $\mathrm{A}$ and $\mathrm{I}$ to the least-squares plane defined by the central two pyridyl rings $\mathrm{D}$ and $\mathrm{F}$ (red characters in Figure 1a) were $d_{\mathrm{A}-\mathrm{DF}}=1.946 \AA$ and $d_{\mathrm{I}-\mathrm{DF}}=1.586 \AA$, while in 
$[2]^{+}$they were $d_{\mathrm{A}-\mathrm{DF}}=1.984 \AA$ and $d_{\mathrm{I}-\mathrm{DF}}=1.040 \AA$ (Figure $\left.1 \mathrm{~b}\right)$. The sum of the two values in $[1]^{+}\left(\Sigma d_{\mathrm{A} / \mathrm{I}-\mathrm{DF}}=3.532\right)$ is about $17 \%$ larger than that in $[2]^{+}\left(\sum d_{\mathrm{A} / \mathrm{I}-\mathrm{DF}}=3.024\right)$, indicating a more helical geometry for the bis-cyclometalated complex $[1]^{+}$, possibly as a consequence of the repulsion between the terminal negatively charged carbon atoms. A difference in helical distortion was also found in the angle of the centroids of ring $\mathrm{A}$ and I with the $\mathrm{Au}(\mathrm{III})$ center $\left(\theta_{\mathrm{Au}-\mathrm{AI}}\right)$. The $\theta_{\mathrm{Au}-\mathrm{AI}}$ of $[1]^{+}$was $54.16^{\circ}$, which was larger than that for $[2]^{+}\left(\theta_{\mathrm{Au}-\mathrm{AI}}=46.66^{\circ}\right)$, demonstrating again the larger distortion in $[1]^{+}$than in $[2]^{+}$. Some $\mathrm{Au}(\mathrm{III})$ complexes have been shown to interact via supramolecular $\mathrm{Au}$...Au bonds. ${ }^{57}$ However, in the crystal lattice of $[1] \mathrm{Cl}$ and $[2]\left(\mathrm{AuCl}_{4}\right)$, the metal centers were too far from each other $(d(\mathrm{Au} \cdots \mathrm{Au}) \sim 4.2-5.5 \AA)$ to suggest any aurophilic interactions. On the other hand, intermolecular $\pi-\pi$ stacking occurs between the quinoline rings of two adjacent molecules $(\pi-\pi$ distance around $3.9 \AA$ in $[1] \mathrm{Cl}$, Figure S1), leading to an interesting supramolecular packing of the helixes (Figure 1c). The crystal structure of $[2]\left(\mathrm{AuCl}_{4}\right)$ showed slightly different supramolecular helical arrangements cut by the larger $\mathrm{AuCl}_{4}{ }^{-}$ counteranions, placed at a relatively short $\mathrm{Au} \cdots \mathrm{Au}$ distance (around $4.27 \AA$, Figure 1c). These packing differences are a probable consequence of the higher distortion of the coordination sphere in $[1]^{+}$combined with the smaller size of chloride counter-anions, which leads to the generation of tighter intermolecular $\pi-\pi$ stacking.

\section{DFT Calculation of the Classical and Rollover Complexes}

Considering the structural similarity between both ligands $\mathrm{H}_{2}$ biqbpy 1 and $\mathrm{H}_{2}$ biqbpy 2 and the different coordination modes obtained in $[1]^{+}$and $[2]^{+}$using identical reaction conditions, we investigated by DFT calculations at the PBE0/ $\mathrm{TZP} / \mathrm{COSMO}$ level the influence of rollover cyclometalation on the frontier orbitals of $[1]^{+}$and the cause(s) of the rollover observed for $[1]^{+}$. As shown in Figure 2, both $[1]^{+}$and $[2]^{+}$show similar highly distorted coordination structures in the DFT minimized structures, with a short $\pi-\pi$ distance on the centroid of the terminal ring of the quinoline groups (4.55 and $4.06 \AA$ for $[1]^{+}$and $[2]^{+}$, respectively, Table 1$)$. The HOMO orbitals of

Table 1. Calculated Information of Complexes $[1]^{+},[2]^{+}$, $[1 \mathrm{a}]^{+}$and $[2 \mathrm{a}]^{+}$

\begin{tabular}{cccccc} 
complex & HOMO & LUMO & $\begin{array}{c}\Delta E \\
(\mathrm{eV})\end{array}$ & $\begin{array}{c}\text { relative total } \\
\text { bind energy } \\
(\mathrm{eV})\end{array}$ & $\begin{array}{c}\text { end ring } \pi-\pi \\
\text { distance }(\AA)\end{array}$ \\
\hline$[1]^{+}$ & -6.028 & -2.520 & 3.508 & 0 & 4.55 \\
{$[2]^{+}$} & -6.118 & -3.267 & 2.851 & +0.8790 & 4.06 \\
{$[1 \mathrm{a}]^{+}$} & -5.707 & -3.096 & 2.611 & +0.7726 & 6.70 \\
{$[2 \mathrm{a}]^{+}$} & -6.332 & -2.586 & 3.746 & -0.6004 & 7.29 \\
\hline
\end{tabular}

both $[1]^{+}$and $[2]^{+}$have similar $\pi$-symmetry and similar energies $\left(-6.028 \mathrm{eV}\right.$ for $[1]^{+},-6.118 \mathrm{eV}$ for $\left.[2]^{+}\right)$and are both centered on the ligand with a negligible contribution of the $\mathrm{Au}(\mathrm{III})$ center $\left(2.2 \%\right.$ for $[1]^{+}, 0 \%$ for $\left.[2]^{+}\right)$. By contrast, they show significantly different LUMO orbitals. The LUMO of $[1]^{+}$was found centered on the bipyridine part of the ligand, while that of $[2]^{+}$ was essentially the expected antibonding combination of the $\mathrm{Au}$ (III) $\mathrm{d}_{x^{2}-y^{2}}$ orbitals (33\%) and the $\mathrm{p}$ orbitals of the coordinated nitrogen atoms, which altogether results in drastically different LUMO energies $\left(-2.520 \mathrm{eV}\right.$ for $[1]^{+}$vs -3.267 for $\left.[2]^{+}\right)$. Consequently, $[1]^{+}$is predicted to be much more difficult to reduce than $[2]^{+}$, as expected for cyclometalated complexes. Moreover, the HOMO-LUMO energy gaps of $[1]^{+}$and $[2]^{+}$are very different, i.e., $3.51 \mathrm{eV}$ in $[1]^{+}$and $2.61 \mathrm{eV}$ in $[2]^{+}$, suggesting that both isomers should have different absorbance spectra. This hypothesis was further confirmed by time-dependent density functional theory calculations (TDDFT) using COSMO to simulate solvent effects in water. As shown in Figure S3, the classical N-bonded $[2]^{+}$exhibited a red-shifted lowest-energy transition $(694 \mathrm{~nm})$, compared with that of the cyclometalated $[1]^{+}(451 \mathrm{~nm})$.

To understand the reason for rollover cyclometalation, we also simulated by DFT the tetrapyridyl coordination mode of biqbpyl $^{2-}$ (the isomer of $[1]^{+}$called $[1 \mathrm{a}]^{+}$, Figure $2 \mathrm{a}$ ) and the rollover cyclometalated binding mode of biqbpy $2^{2-}$ (the isomer of $[2]^{+}$called $[2 \mathrm{a}]^{+}$, Figure $\left.2 \mathrm{~b}\right)$. In the rollover cyclometalated binding mode $[1]^{+}$and $[2 \mathrm{a}]^{+}$, the HOMO and LUMO orbitals showed similar metal-independent $\pi$-symmetry and a LUMO located on the bipyridine ligand. The tetrapyridyl molecules $[2]^{+}$ and $[1 \mathrm{a}]^{+}$shared similar metal-independent, $\pi$-symmetry HOMO orbitals; however, their LUMO orbitals were centered on the $\mathrm{Au}-\mathrm{N}_{4}$ antibonding $\mathrm{d}_{x}{ }^{2}-\mathrm{y}^{2}-\mathrm{p}_{x, y}$ interaction, suggesting that, upon reduction, coordination of the tetrapyridyl ligand to the metal might be weakened. Interestingly, the relative total binding energies of both cyclometalated molecules $[1]^{+}$and $[2 \mathrm{a}]^{+}$were found to be significantly lower than those of $[1 \mathrm{a}]^{+}$ and $[2]^{+}$(Table 1 ). This result suggested that the thermodynamic stability of $[1]^{+}$and $[2]^{+}$might not be the only factor influencing which isomer is obtained in the reaction conditions and hence that both reactions were under kinetic control. However, it should also be noted that both hypothetical structures $[1 \mathrm{a}]^{+}$and $[2 \mathrm{a}]^{+}$show much longer centroid-centroid distances (6.70 and $7.29 \AA$, respectively) between the terminal rings of the quinolines, compared with that in the isomers obtained experimentally $[1]^{+}$and $[2]^{+}$(4.55 and $4.06 \AA$, respectively). This difference also suggests that intramolecular $\pi-\pi$ stacking of the quinoline moieties may play an important role in the mechanism leading to the final structures and hence in the occurrence of rollover cyclometalation for $[1]^{+} .^{40}$ Overall, a probable mechanism for the $\mathrm{C}-\mathrm{H}$ activation of rollover $[1]^{+}$is described in Figure $2 \mathrm{c}$. First, the precursor $\mathrm{HAuCl}_{4}$ reacts with $\mathrm{H}_{2}$ biqbpyl to generate the first intermediate [Au(H2biqbpyl)$\left.\mathrm{Cl}_{2}\right] \mathrm{Cl}$, in which the $\mathrm{Au}(\mathrm{III})$ center bind with the bipyridine part and two chloride ligands. In a second step, the intramolecular $\mathrm{C}-\mathrm{H} \cdots \mathrm{Cl}$ hytrogen bond weakens the $\mathrm{C}-\mathrm{H}$ bond, which triggers the generation of the first $\mathrm{M}-\mathrm{C}$ bond and the second intermediate $[\mathrm{Au}(\mathrm{Hbiqbpy} \mathrm{l}) \mathrm{Cl}] \mathrm{Cl}$. Repeating this process a second time finally results in the rollover bis-cyclometalated $[1] \mathrm{Cl}$.

\section{Behavior in Solution}

The absorbance spectra of both complexes in PBS solution at $310 \mathrm{~K}$ presented no significant changes over $24 \mathrm{~h}$ (Figure S4), suggesting that they were thermally stable in aqueous solutions. [2] $\mathrm{Cl}$ had a significant intense metal-to-ligand charge transfer (MLCT) absorbance band around 450-500 nm, while that of [1]Cl was not remarkable, matching well with the trend observed by DFT and TDDFT calculation. However, when dissolving the complexes $(50 \mu \mathrm{M})$ in PBS containing GSH (100 $\mu \mathrm{M})$, the two complexes showed completely different behavior. The absorbance spectra of [2]Cl rapidly changed (in $<30 \mathrm{~s}$ ), with a significant decrease of the absorption band in the visible region of the spectrum, which hereafter remained stable (for 25 $\mathrm{min})$, while the spectrum of [1] Cl remained constant in these conditions (Figure 3a). The fast reaction of [2] Cl with GSH suggested that reduction of $\mathrm{Au}(\mathrm{III})$ to $\mathrm{Au}(\mathrm{I})$ might take place. $^{58}$ 
a

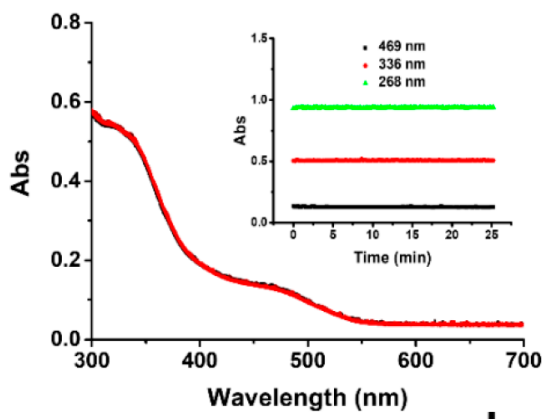

b

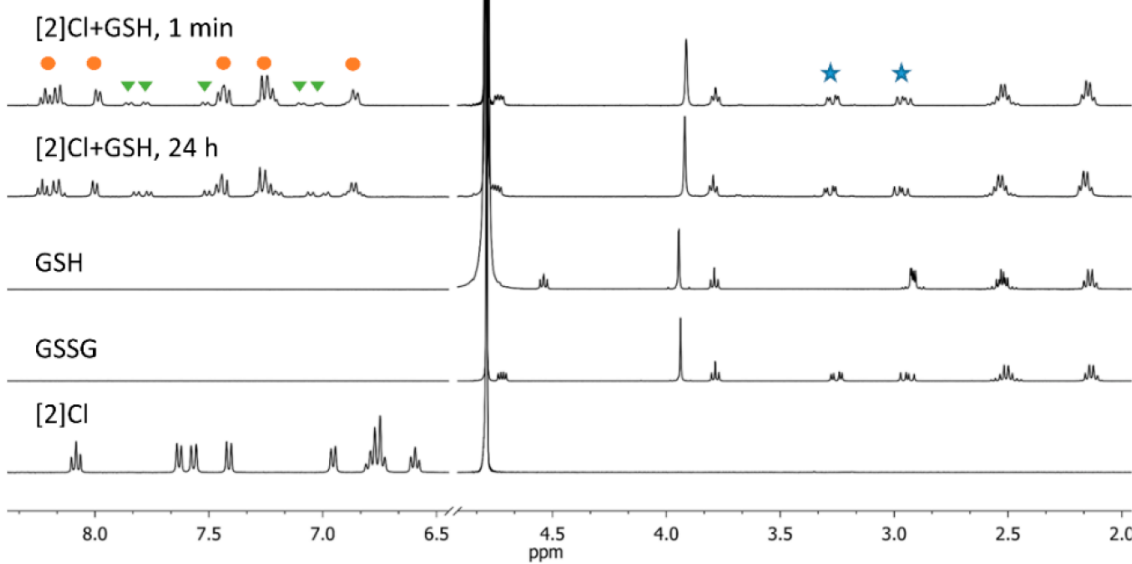

c

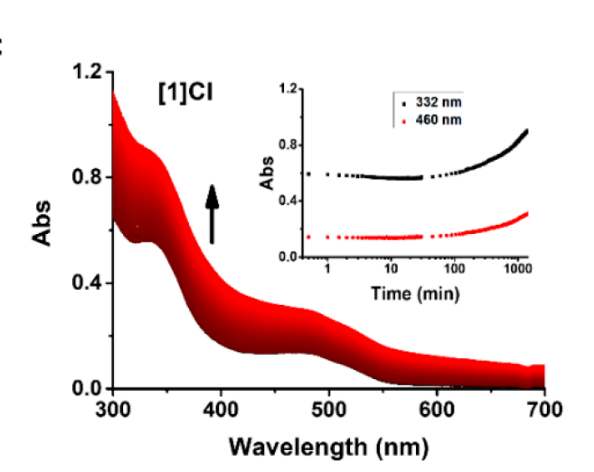

d
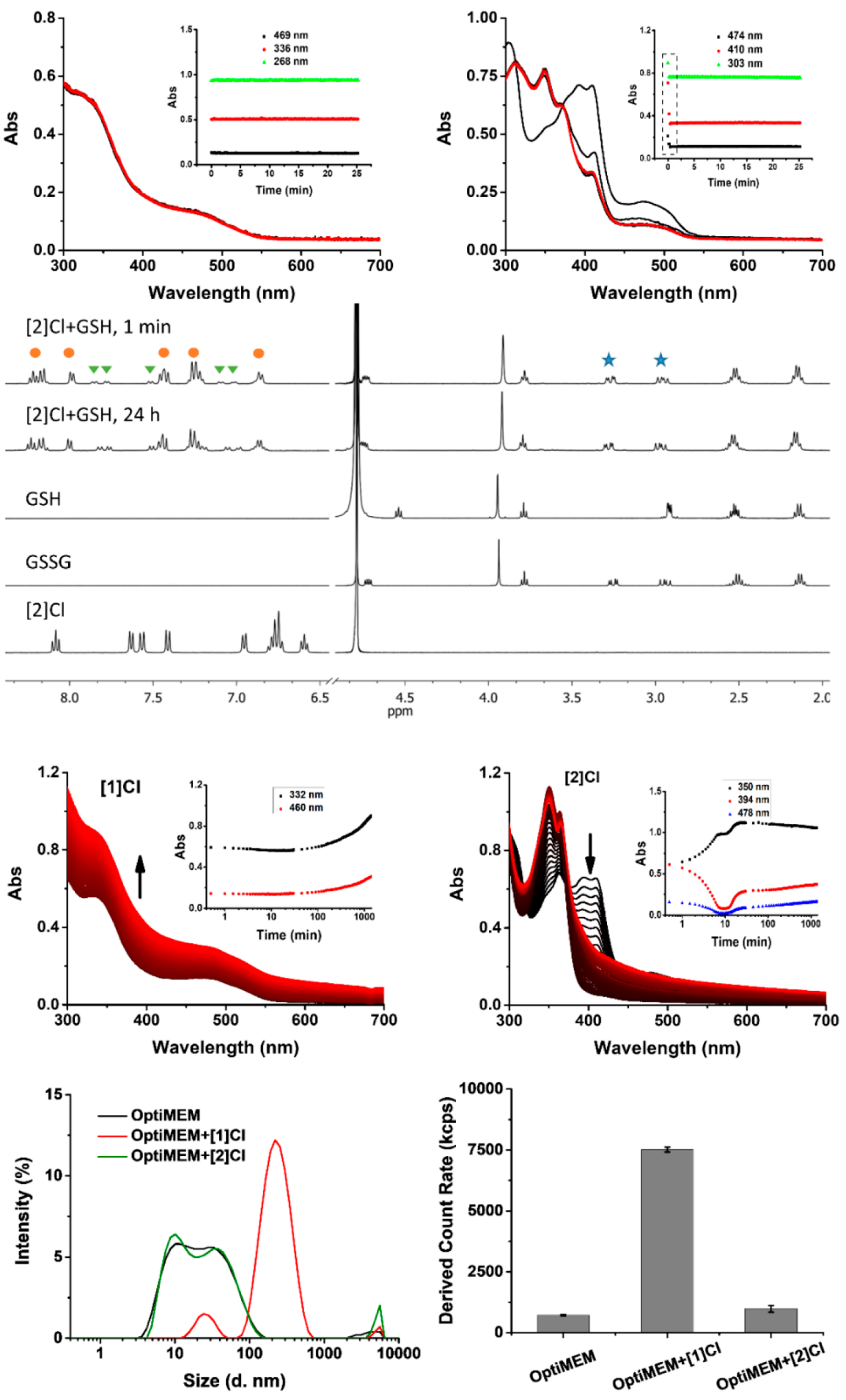

Figure 3. (a) Time evolution of the absorbance spectrum of [1] Cl and [2] Cl $(50 \mu \mathrm{M})$ in PBS solution containing GSH (100 $\mu \mathrm{M})$ for 25 min:

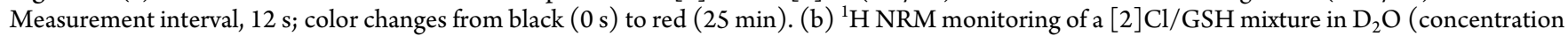
ratio $3 \mathrm{mM} / 6 \mathrm{mM}$ ). Orange circle and green triangle indicate different $\mathrm{Au}(\mathrm{I})$ species. (c) Time evolution of the absorbance spectrum of [1]Cl and [2] $\mathrm{Cl}(50 \mu \mathrm{M})$ in Opti-MEM medium solution containing FCS $(2.5 \% \mathrm{v} / \mathrm{v})$ for $24 \mathrm{~h}$. Measurement interval, first 30 min every $0.5 \mathrm{~min}$, the left $23.5 \mathrm{~h}$ every $15 \mathrm{~min}$; color changes from black (0 s) to red (25 min). (d) DLS size distribution and derived count rate of [1]Cl and [2]Cl (50 $\mu \mathrm{M})$ in Opti-MEM medium solution containing FCS $(2.5 \% \mathrm{v} / \mathrm{v})$.

In order to check this, ${ }^{1} \mathrm{H}$ NMR was used to monitor the reaction between [2] Cl and $\mathrm{GSH}$ in $\mathrm{D}_{2} \mathrm{O}$, using a complex/GSH ratio of 1:2. After mixing GSH with [2] Cl, the ${ }^{1} \mathrm{H}$ NMR peaks of [2] Cl showed a dramatic change, accompanied by the generation of a peak for GSSG in the aliphatic region (2.98 and $3.26 \mathrm{ppm}$, blue star in Figure $3 \mathrm{~b}$ ). Although the peaks in the aromatic region can be split into two different $\mathrm{Au}(\mathrm{I})$ species involving the $\mathrm{H}_{2}$ biqbpy2 ligand (indicated as yellow circle or green triangle in Figure $3 \mathrm{~b}$ ), their interpretation is difficult. After $24 \mathrm{~h}$, a precipitate was formed, which after filtration and ${ }^{1} \mathrm{H}$ NMR analysis was found to be the free tetrapyridyl ligand (Figure S5). These UV-vis and NMR spectroscopy experi- 
Table 2. Half-Maximal Effective Concentrations $\left(\mathrm{EC}_{50}\right.$ in $\left.\mu \mathrm{M}\right)$ of Gold Complexes [1] Cl and [2] Cl and Cisplatin toward 2D Cancer Cell and Healthy Cell Monolayers in Normoxic $\left(21 \% \mathrm{O}_{2}\right)$ and Hypoxic $\left(1 \% \mathrm{O}_{2}\right)$ Conditions $^{a}$

\begin{tabular}{|c|c|c|c|c|c|c|c|c|c|c|c|c|c|}
\hline \multirow[b]{2}{*}{ complex } & & \multicolumn{12}{|c|}{$\mathrm{EC}_{50}(\mu \mathrm{M})$} \\
\hline & & A549 & $\pm \mathrm{CI}$ & A431 & $\pm \mathrm{CI}$ & A375 & $\pm \mathrm{CI}$ & MCF7 & $\pm \mathrm{CI}$ & MRC5 & $\pm \mathrm{CI}$ & A549-3D & $\pm \mathrm{CI}$ \\
\hline \multirow[t]{2}{*}[1]{$\mathrm{Cl}_{2}$} & normoxic & 3.3 & $+0.7,-0.6$ & 4 & $+1,-1$ & 5 & $+1,-1$ & 4 & $+1,-1$ & 27 & $+16,-9$ & 7 & $+4,-2$ \\
\hline & hypoxic & 5 & $+2,-2$ & 16 & $+7,-5$ & 6 & $+3,-2$ & 9 & $+2,-1$ & 28 & $+9,-6$ & ND & \\
\hline \multirow[t]{2}{*}[2]{$\mathrm{Cl}$} & normoxic & 3.1 & $+0.3,-0.3$ & 3.5 & $+0.6,-0.5$ & 0.7 & $+0.2,-0.1$ & 0.3 & $+0.1,-0.1$ & 3.3 & $+0.8,-0.7$ & 4 & $+3,-2$ \\
\hline & hypoxic & 3.9 & $+0.7,-0.6$ & 2.9 & $+0.8,-0.5$ & 4 & $+4,-2$ & 2.1 & $+0.1,-0.1$ & 1.5 & $+0.2,-0.2$ & ND & \\
\hline \multirow[t]{2}{*}{ cisplatin } & normoxic & 4.5 & $+0.7,-0.6$ & 1.8 & $+0.5,-0.4$ & 1.2 & $+0.1,-0.1$ & 3.6 & $+1.2,-0.9$ & 5.8 & $+1.5,-1.2$ & 0.8 & $+0.3,-0.2$ \\
\hline & hypoxic & 24 & $+11,-5$ & 13 & $+4,-3$ & 3.4 & $+0.8,-0.7$ & $\mathrm{ND}$ & & 9.4 & $+5.7,-3.6$ & $\mathrm{ND}$ & \\
\hline
\end{tabular}

${ }^{a} 95 \%$ confidence interval values ( $\mathrm{CI}$ in $\mu \mathrm{M}$ over three independent biological experiments) are also indicated. ND: not determined.
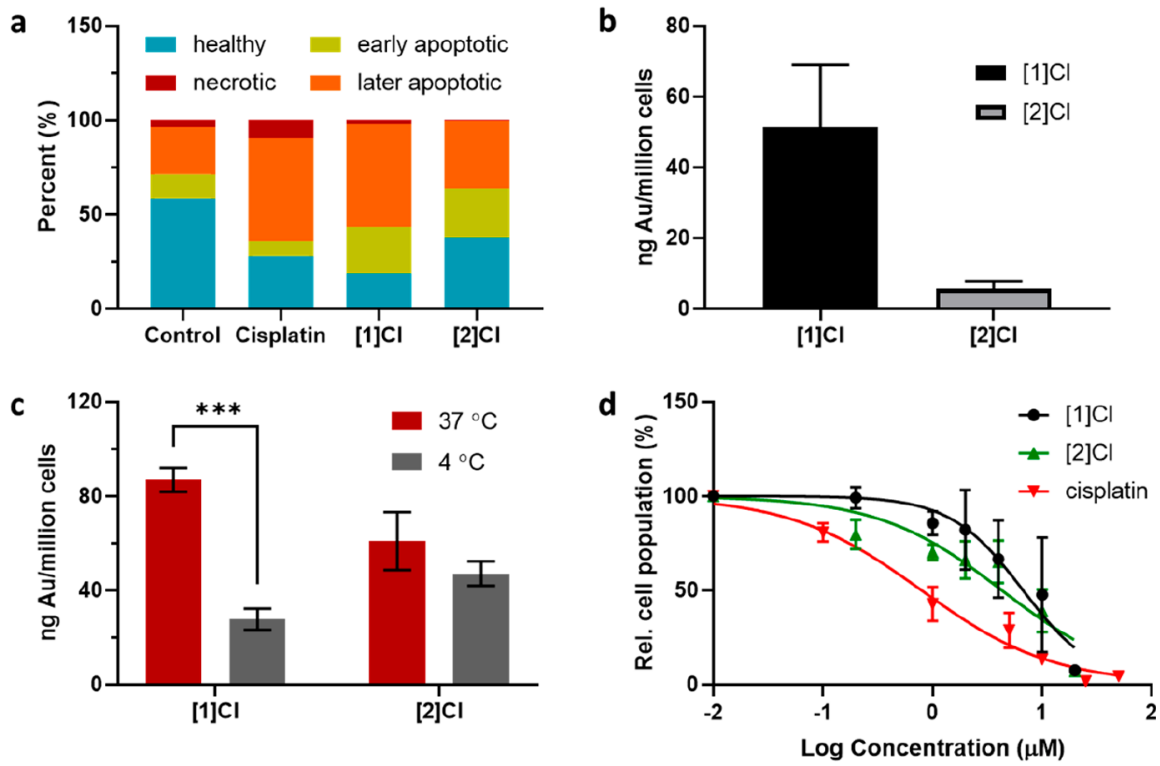

Figure 4. (a) Flow cytometry quantification of healthy, early apoptotic, later apoptotic, and necrotic A549 cells after treatment with cisplatin (15 $\mu \mathrm{M})$, [1] Cl $(10 \mu \mathrm{M})$, or [2] $\mathrm{Cl}(10 \mu \mathrm{M})$ for $24 \mathrm{~h}$. (b) Au content (ICP-MS) of A549 cells after treatment with [1]Cl or [2]Cl (1 $\mu \mathrm{M})$ for 24 h. (c) Intracellular Au content (according to ICP-MS) for A549 cells treated with $[1] \mathrm{Cl}$ or $[2] \mathrm{Cl}(5 \mu \mathrm{M})$ for $2 \mathrm{~h}$ at 4 or $37^{\circ} \mathrm{C}$. (d) $\mathrm{EC}_{50}$ values for $[1] \mathrm{Cl}$, [2] Cl, or cisplatin in 3D multicellular tumor spheroids of A549 cells, based on a 3D CellTiterGlo ATP end-point assay.

ments demonstrate that [2] $\mathrm{Cl}$ is easily reduced by $\mathrm{GSH}$, while $[1] \mathrm{Cl}$ is much more stable in the presence of GSH, suggesting that the rollover cyclometalation stabilizes the gold complexes in thiol-containing solutions.

The reactivity of both complexes in the cell-growing medium Opti-MEM complete (containing 2.5\% fetal calf serum (FCS)) was also studied for $24 \mathrm{~h}$ using absorption spectroscopy (Figure $3 \mathrm{c})$. For $[1] \mathrm{Cl}$, only the baseline of the spectrum increased gradually, suggesting the formation of nanoparticles, but there was no obvious reaction or isosbestic point, suggesting the coordination sphere of the metal did not change in such conditions. By contrast, the absorbance band of $[2] \mathrm{Cl}$ in the visible region exhibited a rapid decrease during the first $10 \mathrm{~min}$ and finally disappeared without any spectroscopic signature for increased scattering, suggesting that a chemical reaction occurred in the medium leading to a change of the $\mathrm{Au}$ coordination sphere, while nanoaggregation did not take place. Considering these results, reduction by thiol species present in the medium, like GSH or serum albumin, is the most likely explanation for the reaction of the $\mathrm{Au}(\mathrm{III})$ complex [2] $\mathrm{Cl}$ in FCS-containing medium. The nanoparticle formation observed for $[1] \mathrm{Cl}$ in the cell medium was confirmed by dynamic light scattering measurements (DLS, Figure 3d): the Opti-MEM solution of $[1] \mathrm{Cl}$ showed a significant signature of nanoparticles in the range $100-500 \mathrm{~nm}$ and much higher particle numbers than the Opti-MEM control and [2] Cl groups did. Aggregation of $[1] \mathrm{Cl}$ was found to be water-dependent. In pure DMSO- $d_{6}$, the ${ }^{1} \mathrm{H}$ NMR spectra of [1] Cl were found to be identical (Figure $\mathrm{S} 2 \mathrm{a})$ at high $(5 \mathrm{mg} / \mathrm{mL})$ and low $(1 \mathrm{mg} / \mathrm{mL})$ concentrations, indicating that supramolecular aggregation did not take place in such conditions. When varying amounts of water were added, however, the ${ }^{1} \mathrm{H}$ NMR spectrum changed dramatically: when the DMSO- $d_{6} / \mathrm{H}_{2} \mathrm{O}$ ratio decreased from 10:0 to 5:5 (Figure $\mathrm{S} 2 \mathrm{~b})$, most aromatic peaks broadened while the signal/noise ratio became lower, indicating the formation of aggregates. It was impossible to interpret these changes in terms of specific supramolecular interactions; simple polarity changes of the solvent would also lead to aggregation of slightly hydrophobic molecules $\left(\log P_{\text {ow }}=+0.85\right)$. Transmission electron microscopy (TEM) was finally used to determine the size and morphology of the aggregates generated by incubation of $[1] \mathrm{Cl}$ in cell-growing medium. The TEM images obtained for a sample of $[1] \mathrm{Cl}$ in Opti-MEM complete (Figure S6) showed high-contrast spherical nanoparticles, while a control sample only showed regular crystals typical for the crystallization of salts, and a sample containing [2] $\mathrm{Cl}$ showed large amorphous particles that can be attributed to the precipitate generated upon applying vacuum before running TEM imaging. The average particle diameter measured in the image of [1] Cl was $76 \pm 20 \mathrm{~nm}$, which is slightly smaller than the hydrodynamic diameter determined 
by DLS; this effect is very common and has been well-explained in the literature. ${ }^{59}$ In summary, the $\mathrm{Au}(\mathrm{III})$ center in $[1] \mathrm{Cl}$ is stable to reduction by thiol groups present in, e.g., GSH- or FCScontaining medium, proving that bis-cyclometalation results in the stabilization of $\mathrm{Au}(\mathrm{III})$. However, the rollover cyclometalated complex interacts supramolecularly in DMSO/water mixtures, and when dissolved in cell growing medium it forms nanoparticles. By contrast, [2] Cl does not form nanoparticles in cell growing medium, but its $\mathrm{Au}$ (III) center is sensitive to reduction by thiol groups, which is a direct consequence of the high electronegativity and positive charge of the $\mathrm{Au}$ (III) center. Reduction by thiols generates a $\mathrm{Au}(\mathrm{I})$ intermediate complex, which is followed by slow release of the insoluble tetrapyridyl ligand and concomitant formation of gold(I) ions probably bound to GSH. ${ }^{60}$

\section{Anticancer Properties}

The cytotoxicity of both gold complexes [1] $\mathrm{Cl}$ and [2] $\mathrm{Cl}$ against 2D monolayers of four human cancer cell lines (lung cancer A549, skin cancer A431, melanoma cancer A375, and breast cancer MCF7) and one noncancerous cell line (MRC5) was determined using a reported SRB assay, both in normoxic and hypoxic conditions. ${ }^{61}$ The half-maximal effective concentrations $\left(\mathrm{EC}_{50}\right.$ in $\left.\mu \mathrm{M}\right)$, defined as the concentration necessary to kill $50 \%$ of the cells, compared to untreated wells, are shown in Table 2 (dose-response curves are shown in Figures S7-S9). Similar to cisplatin, $[1] \mathrm{Cl}$ showed a broad-spectrum anticancer ability with $\mathrm{EC}_{50}$ values in all cancer cells in the range of $3.3-16 \mu \mathrm{M}$, in both normoxic and hypoxic conditions. Interestingly, [1] $\mathrm{Cl}$ exhibited a relatively higher $\mathrm{EC}_{50}$ value of 27 and $28 \mu \mathrm{M}$ in normoxic and hypoxic conditions, respectively, in noncancerous MRC5 cells, suggesting some form of selectivity toward cancer cells for $[1] \mathrm{Cl}$. By comparison, [2] $\mathrm{Cl}$ showed generally lower $\mathrm{EC}_{50}$ values to cancer cells, i.e., higher cytotoxicity, with significant antiproliferative properties against $\mathrm{A} 375$ and MCF7 cancer cells $\left(\mathrm{EC}_{50}=0.7\right.$ and $0.3 \mu \mathrm{M}$, respectively, in normoxic conditions). In addition, [2] Cl also showed high cytotoxicity to healthy MRC5 cells (3.3 and $1.5 \mu \mathrm{M}$ in normoxic and hypoxic conditions, respectively), which means that $[2] \mathrm{Cl}$ is less selective to cancer cells than [1] Cl. The Annexin V/propidium iodide double staining assay was used in order to investigate what kind of cell death was triggered by [1] $\mathrm{Cl}$ and [2] $\mathrm{Cl}$. The different fluorescence states of both dyes in each cell indicates its status, i.e., healthy $(-/-)$, early apoptotic $(+/-)$, later apoptotic $(+/+)$, or necrotic $(-/+)$. As shown in Figure 4a, $24 \mathrm{~h}$ following treatment with complex [1] $\mathrm{Cl}$ or $[2] \mathrm{Cl}(10 \mu \mathrm{M})$, the percentage of A549 cells in the early and late apoptotic quadrants increased with compound concentration, compared with the control group, suggesting that both [1] $\mathrm{Cl}$ and [2] $\mathrm{Cl}$ kill A549 cells via apoptosis.

In humans, cancer appears as a $3 \mathrm{D}$ tumor characterized by a complicated microenvironment, which greatly influences the permeability, uptake, and cytotoxicity of anticancer drugs. ${ }^{62}$ In recent years, in vitro $3 \mathrm{D}$ tumor spheroids have been developed as a more suitable model for the prescreening of anticancer drugs, as they provide better mimicry of nutrient and drug penetration of in vivo tumors. Thus, the cytotoxicity of both gold complexes was also determined in 3D tumor spheroids, using the final spheroid diameter as well as a fluorescence-based Cell Titer Glo 3D end-point assay quantifying ATP (Figure 4d). ${ }^{63}$ As shown in Figure 4d, [1] Cl showed good antiproliferation properties in $\sim 1000 \mu \mathrm{m}$ diameter A549 tumor spheroids $\left(\mathrm{EC}_{50}\right.$ $=7 \mu \mathrm{M})$, while $[2] \mathrm{Cl}$ exhibited slightly higher cytotoxicity $\left(\mathrm{EC}_{50}\right.$ $=4 \mu \mathrm{M})$. Both were found to be less toxic than cisplatin $\left(\mathrm{EC}_{50}=\right.$
$0.6 \mu \mathrm{M}$ ). Notably, the spheroid diameter (Figures S14 and S15) was found to not be a good measure of the effect of these compounds, as the dose-diameter curves were found to be very different from the dose-response curves using the Cell TiterGlo3D assay. In summary, the cytotoxicity of the two gold complexes remained high in a 3D tumor model, where [2] $\mathrm{Cl}$ kept the higher cytotoxicity observed in a $2 \mathrm{D}$ model.

\section{Mechanistic Studies}

First, cell toxicity strongly depends on drug uptake, so ICP-MS was used to determine the intracellular Au content in A549 cells treated with either compound. At $24 \mathrm{~h}$ after treatment with [1] $\mathrm{Cl}$ or $[2] \mathrm{Cl}(1 \mu \mathrm{M})$, the Au content in A549 cells was 8-fold higher for $[1] \mathrm{Cl}\left(51 \mathrm{ng} \mathrm{Au} / 1 \times 10^{6}\right.$ cells $)$ than for $[2] \mathrm{Cl}(6 \mathrm{ng}$ $\mathrm{Au} / 1 \times 10^{6}$ cells, Figure $\left.4 \mathrm{~b}\right)$, demonstrating the much more efficient cellular uptake of the cyclometalated rollover complex [1] Cl. Although usually cyclometalated complexes have a lower positive charge than that of noncyclometalated analogues, and it is often hypothesized that higher uptake is a consequence of increased passive diffusion through the cell membrane, ${ }^{64}$ here the charges of $[1]^{+}$and $[2]^{+}$are identical, so such interpretation of the higher cellular uptake of $[1] \mathrm{Cl}$ cannot be made. On the one hand, the lower uptake of [2] $\mathrm{Cl}$ might be linked to its decomposition in the cell culture into $\mathrm{Au}^{+}$ions that cannot be taken up efficiently, which also suggests that the toxicity of this complex might be that of the ligand $\mathrm{H}_{2}$ biqbpy2. On the other hand, the higher uptake of [1] Cl might be due to the formation of nanoparticles in the cell medium (see above), which may help to trigger energy-dependent endocytosis-related transport pathways. To check this hypothesis, we compared Au cellular uptake at normal $\left(37^{\circ} \mathrm{C}\right)$ vs low $\left(4^{\circ} \mathrm{C}\right)$ temperature. Most often, nanoparticle uptake is strongly energy-dependent and can be inhibited by lower temperature, ${ }^{65}$ while nonaggregated $[2] \mathrm{Cl}$ (or $\mathrm{Au}^{+}$ions) might be internalized by less energy-dependent processes that are less affected by temperature. As shown in Figure $4 \mathrm{c}$, after treatment with the gold complexes $(5 \mu \mathrm{M})$ and 2 $\mathrm{h}$ incubation, the $\mathrm{Au}$ content of the cells treated with $[1] \mathrm{Cl}$ showed a significant decrease in gold uptake, from $87 \mathrm{ng} \mathrm{Au} / 1 \times$ $10^{6}$ cells at $37^{\circ} \mathrm{C}$ to $28 \mathrm{ng} \mathrm{Au} / 1 \times 10^{6}$ cells at $4{ }^{\circ} \mathrm{C}$, while $[2] \mathrm{Cl}$ only showed a slight decrease, from 61 to $47 \mathrm{ng} \mathrm{Au} / 1 \times 10^{6}$ cells. This result suggested that $[1] \mathrm{Cl}$ may go through the cell membrane by energy-dependent pathways (which may include endocytosis), which is fully compatible with the hypothesis of uptake of a nanoaggregated compound, while cellular uptake of [2] $\mathrm{Cl}$ is taking place more via less energy-dependent pathways. It is interesting to note that in A549 cells the $\mathrm{EC}_{50}$ values under normoxia were very close for $[1] \mathrm{Cl}$ and for $[2] \mathrm{Cl}$, despite the much higher cellular uptake of $[1] \mathrm{Cl}$. Clearly, $[1] \mathrm{Cl}$ is less cytotoxic than $[2] \mathrm{Cl}$, which was also confirmed in the noncancerous cell line MRC5.

In order to see where the complexes might be found in cells, commercial kits were used to fractionate A549 cells treated with [1] Cl or [2] $\mathrm{Cl}(1 \mu \mathrm{M})$ for $24 \mathrm{~h}$ and split them into four fractions (cytosol, membranes, nucleus, and cytoskeletal), the gold content of which was measured by ICP-MS. One should notice that the membrane fraction includes the cell membrane, lysosome, endosome, and mitochondria membranes. As showed in Figure S11 and Table S8, ICP-MS showed that, in cells treated with $[1] \mathrm{Cl}$, the majority of the gold was found in the cytoskeletal $\left(27.2 \mathrm{ng} \mathrm{Au} / 1 \times 10^{6}\right.$ cells, $\left.48 \%\right)$ and membrane $(17 \mathrm{ng} \mathrm{Au} / 1 \times$ $10^{6}$ cells, $\left.30 \%\right)$ fractions, but that $8.6 \mathrm{ng} \mathrm{Au} / 1 \times 10^{6}$ cells $(15 \%)$ was found in the nuclei, while the lowest fraction was found in the cytosol (3.5 $\mathrm{ng} \mathrm{Au} / 1 \times 10^{6}$ cells, 6\%). For [2] Cl, gold uptake 
was, as above, much weaker than that for $[1] \mathrm{Cl}$, and it was distributed only between the membrane $\left(1.1 \mathrm{ng} \mathrm{Au} / 1 \times 10^{6}\right.$ cells, $63 \%)$ and cytosol $\left(0.61 \mathrm{ng} \mathrm{Au} / 1 \times 10^{6}\right.$ cells, $\left.37 \%\right)$ fractions, while the metal concentration for both the nucleus and cytoskeletal fractions remained lower than the detection limit. These ICP-MS data not only highlighted that the intracellular gold distribution with both compounds was completely different but also demonstrated that $[1] \mathrm{Cl}$ can be found in significant amounts in the nuclei and in membranes, while gold in cells treated with $[2] \mathrm{Cl}$ does not penetrate the nucleus but can be found in low amounts in the cytosol, where it may be able to interact with TrxR.

The important resistance of $1[\mathrm{Cl}]$ against intracellular thiols makes it similar to the so-called "delocalized lipophilic cations" (DLCs) ${ }^{66,67}$ DLCs are known to be selectively cytotoxic to carcinoma cells because of their direct interference with mitochondrial functions and in particular the depolarization of the mitochondrial membrane. To check whether $[1] \mathrm{Cl}$ was indeed acting as a DLC, we measured the influence of both gold complexes on the mitochondrial membrane potential by using tetramethylrhodamine ethyl ester (TRME), a cell-permeant, positively charged dye that readily accumulates in active mitochondria due to their relative negative charge. ${ }^{45}$ As shown in Figure S12, after $24 \mathrm{~h}$ treatment of A549 cells with [1]Cl or [2] Cl $(20 \mu \mathrm{M})$, according to FACS analysis both complexes showed very limited influence on the mitochondrial membrane potential, which was very similar to that of the negative control group, while the positive control group treated with carbonyl cyanide $m$-chlorophenyl hydrazone treatment (CCCP, $20 \mu \mathrm{M}, 1$ h) showed dramatically reduced percentage of intact mitochondrial membranes. ${ }^{68}$ Moreover, DNA gel experiments using the pUC19 plasmid (Figure S13) demonstrated that [1]Cl had concentration-dependent, DNA-binding, and single-strand DNA cleavage properties, while [2]Cl did not show any significant DNA-binding or DNA-cleavage properties. To sum up, the two gold complexes were not interfering with the mitochondrial membrane in the tested conditions, while intracellular gold uptake and DNA gel electrophoresis experiments indicated that the cytotoxicity of $[1] \mathrm{Cl}$ might be partially attributed to its DNA cleavage property, whereas for [2] Cl its cytotoxicity is clearly independent of DNA interactions.

\section{Proteins Binding and Inhibition Properties}

Several gold complexes have been demonstrated to show significant binding and inhibition properties to several proteins, such as urease, ${ }^{69}$ aquaporin, ${ }^{70}$ and particularly TrxR. ${ }^{11,60}$ To determine the inhibition properties of $[1] \mathrm{Cl}$ and $[2] \mathrm{Cl}$ toward mammalian TrxR, a spectrophotometric assay was realized using commercially available rat liver TrxR. As shown in Table 3, [1] $\mathrm{Cl}$ did not show any inhibition activity to TrxR at the tested concentration. This low inhibition property might be attributed

Table 3. Binding of Tetrapyridyl Ligands and Their Au(III) Complexes to TrxR and $\mathrm{K}_{\mathrm{v}} 11.1$ Proteins

\begin{tabular}{llcc}
\multicolumn{1}{c}{ compd } & $\begin{array}{c}\text { TrxR inhibition } \\
\mathrm{IC}_{50}(\mu \mathrm{M})\end{array}$ & $\begin{array}{c}\left.{ }^{3} \mathrm{H}\right] \text { dofetilide binding } \\
\text { remaining }(\%)^{b}\end{array}$ & $\begin{array}{c}\mathrm{K}_{\mathrm{v}} 11.1 \\
\text { binding }(\%)^{c}\end{array}$ \\
$\mathrm{H}_{2}$ biqbpy1 & $\mathrm{ND}^{a}$ & $64 \pm 4$ & $36 \pm 4$ \\
{$[1] \mathrm{Cl}$} & $>5$ & $8.7 \pm 0.1$ & $91.3 \pm 0.1$ \\
$\mathrm{H}_{2}$ biqbpy2 & $\mathrm{ND}$ & $16 \pm 4$ & $84 \pm 4$ \\
{$[2] \mathrm{Cl}$} & $0.13 \pm 0.02$ & $7.9 \pm 0.2$ & $92.1 \pm 0.2$
\end{tabular}

${ }^{a} \mathrm{ND}=$ not determined. ${ }^{b}$ tested concentration $=10 \mu \mathrm{M} .{ }^{c} \mathrm{~K}_{\mathrm{v}} 11.1$ binding $(\%)=100 \%-\left[{ }^{3} \mathrm{H}\right]$ dofetilide binding remaining (\%). to the weak reactivity of [1]Cl with biological thiols (see above). By contrast, [2]Cl showed significant TrxR inhibition activity, with a submicromolar $\mathrm{IC}_{50}(0.13 \pm 0,02 \mu \mathrm{M})$, which may be attributed to its high reactivity with reducing thiols, which generates $\mathrm{Au}^{+}$ions that are known inhibitors of TxrR. The significant difference between $[1] \mathrm{Cl}$ and $[2] \mathrm{Cl}$ indicates that rollover cyclometalation might represent a promising design strategy to generate anticancer gold compounds that show a target different from TxrR and do not release polypyridyl ligands upon reacting with cell medium or intracellular GSH.

Indeed, next to releasing $\mathrm{Au}^{+}$ions, reduction of $[2] \mathrm{Cl}$ by biological thiols also leads to the release of the free polypyridyl ligand $\mathrm{H}_{2}$ biqbpy2, which might have unselective toxicity. This hypothesis stimulated us to look into the biological activity of the two polypyridyl ligands $\mathrm{H}_{2}$ biqbpyl and $\mathrm{H}_{2}$ biqbpy2. $\mathrm{N}$ Heterocyclic ligands are found in roughly $60 \%$ of FDA-approved drugs, and pyridine ring systems are prominent examples of such fragments. ${ }^{71}$ Many N-heterocyclic ligands have been considered as potential inhibitors of potassium channels in the cell membrane or mitochondrial membrane. ${ }^{72-74}$ Potassium channels have been proposed as emerging targets in cancer therapy for their overexpression in several cancer cell lines and their specific functions in cell proliferation as they control cell cycle progression. ${ }^{75,76}$ On the other hand, a classical safety issue in medicinal chemistry is $\mathrm{K}^{+}$channel inhibition, in particular the broad-substrate $\mathrm{K}_{\mathrm{v}} 11.1$ (hERG) potassium channel, which is known to generate cardiac toxicity in vivo. ${ }^{77-79}$ Here, we evaluated the $\mathrm{K}_{\mathrm{v}} 11.1$ channel interaction of the two gold complexes $[1] \mathrm{Cl}$ and $[2] \mathrm{Cl}$ and their ligands $\mathrm{H}_{2}$ biqbpyl and $\mathrm{H}_{2}$ biqbpy 2 at a single concentration $(10 \mu \mathrm{M})$ in a $\left[{ }^{3} \mathrm{H}\right]$ dofetilide displacement assay. ${ }^{80}$ When a compound binds to the $\mathrm{K}_{\mathrm{v}} 11.1$ channel, the binding of the reference hERG blocker $\left[{ }^{3} \mathrm{H}\right]$ dofetilide is decreased, which is used to quantify the $\mathrm{K}_{\mathrm{v}} 11.1$ binding efficiency of the tested compounds. As shown in Table 3 , all four compounds displaced $\left[{ }^{3} \mathrm{H}\right]$ dofetilide from the channel albeit to different degrees. While $\mathrm{H}_{2}$ biqbpyl was a poor binder, $\mathrm{H}_{2}$ biqbpy 2 displaced $84 \%$ of $\left[{ }^{3} \mathrm{H}\right]$ dofetilide binding. The gold complexes showed a (slightly) higher effect, i.e., 91\% displacement for the rollover compound $[1] \mathrm{Cl}$ and $92 \%$ displacement for [2] Cl. Altogether, both [1] $\mathrm{Cl}$ and [2] Cl efficiently bind to the $\mathrm{K}_{\mathrm{v}} 11.1$ channel, and while [2] Cl and $\mathrm{H}_{2}$ biqbpy2 had similar $\mathrm{K}_{\mathrm{v}} 11.1$ binding, for $\mathrm{H}_{2}$ biqbpyl, rollover coordination to gold(III) leads to appreciably increased binding to $\mathrm{K}_{\mathrm{v}} 11.1$. To evaluate whether ligand release and potassium channel binding may correlate to toxicity, we measured the cell growing inhibition properties $\left(\mathrm{EC}_{50}\right)$ of the two tetrapyridyl ligands in A549 cancer cells. As shown in Figure S10, $\mathrm{H}_{2}$ biqbpyl was nontoxic to A549 cells $\left(\mathrm{EC}_{50}>200 \mu \mathrm{M}\right)$, while $\mathrm{H}_{2}$ biqbpy2 had a rather low $\mathrm{EC}_{50}$ value $(12 \mu \mathrm{M})$ and hence showed appreciable cytotoxicity. Interestingly, these results correlated appreciably to the $\mathrm{K}_{\mathrm{v}} 11.1$ channel binding properties of both ligands: the less toxic ligand $\mathrm{H}_{2}$ biqbpyl bound not very well (36\%) to the potassium channel, while the most cytotoxic ligand $\mathrm{H}_{2}$ biqbpy2 bound significantly better to the membrane protein $(84 \%)$.

\section{DISCUSSION}

Many $\mathrm{Au}(\mathrm{III})$ compounds have been demonstrated to be potential anticancer metallodrugs due to their easy reduction to $\mathrm{Au}(\mathrm{I})$ upon intracellular uptake. $\mathrm{Au}(\mathrm{I})$ species always show strong binding affinity to the thiol groups of many key biomolecules and enzymes inside a cell, notably to glutathione (GSH) or thioredoxin reductase (TrxR), which are overexpressed in cancer cells because they control the redox balance of 
cells. ${ }^{12,81,82}$ However, several cyclometalated Au(III) complexes have been shown to withstand reduction by biological thiols while keeping anticancer properties, indicating that a different anticancer mechanism may be operative. ${ }^{83}$ Very limited research has focused on the comparison of cyclometalated vs classical nitrogen-coordinated gold compounds, both from the chemical structure point of view to that of the biological activities. The two $\mathrm{Au}$ (III) complexes discussed in this work are isomers, that differ solely by (1) the binding mode to the metal center, i.e., rollover cyclometalation for $[1]^{+}$and classical nitrogen coordination for $[2]^{+}$; and (2) the protonation state of the noncoordinated amine bridges, which are protonated in $[1]^{+}$ and deprotonated in $[2]^{+}$. As a result, the two complexes showed strikingly similar helical molecular shapes and strictly identical charges $(+1)$, but they exhibited dramatically different reactivity to $\mathrm{GSH}$ and TrxR proteins: [1] Cl showed no reaction to thiol groups and no TxrR inhibition, while [2] $\mathrm{Cl}$ reacted with thiol groups rather quickly, which is accompanied by the release of the tetradentate ligand and TxrR-inhibiting $\mathrm{Au}^{+}$ions. The low thiol susceptibility of $[1]^{+}$should be attributed to the high stability of the $\mathrm{M}-\mathrm{C}$ bond and of its LUMO orbital, and to the localization of its LUMO on the bipyridine group, without the involvement of metal-ligand bonds. By contrast, in $[2]^{+}$, the LUMO is both high in energy and involves antibonding combination of the metal d orbitals with the ligand lone pair, which leads to easy release of the ligand upon reduction in biological media.

In biological terms, both compounds were found to be anticancer active, but in a quite different manner. On the one hand, [2] $\mathrm{Cl}$ is an interesting cytotoxic compound that upon reduction releases both a TxrR-inhibiting $\mathrm{Au}^{+}$ion and a good $\mathrm{K}_{\mathrm{v}} 11.1 \mathrm{~K}^{+}$-channel blocker ligand $\mathrm{H}_{2}$ biqbpy 2 . However, gold cellular uptake is strongly limited by thiol-induced decomposition before the complex crosses the cell membrane, i.e., outside the cells. When treating the cells with medium containing $[2] \mathrm{Cl}$, it is hence a homogeneous mixture of $\mathrm{Au}^{+}$ ions and $\mathrm{H}_{2}$ biqbpy 2 ligand, probably stabilized in solution by BSA, that reaches the cells. The resulting toxicity in A549 cells $\left(\mathrm{EC}_{50}=3.1 \mu \mathrm{M}\right)$ is higher for $[2] \mathrm{Cl}$ than for $\mathrm{H}_{2}$ biqbpy $2\left(\mathrm{EC}_{50}=\right.$ $12 \mu \mathrm{M})$, suggesting that although $\mathrm{Au}(\mathrm{I})$ ions are taken up in low amounts, they may contribute, by their TrxR-inhibiting properties, to the overall toxicity of the gold compound. At this stage, we do see a correlation between the toxicity of tetrapyridyl ligands and their ability to bind to hERG potassium channels, but in the absence of more advanced mechanistic observations it is not yet possible to conclude that the $\mathrm{K}_{\mathrm{v}} 11.1$ channel binding properties of $\mathrm{H}_{2}$ biqbpy 2 are responsible for its cell-killing properties. Overall, Au(III) complexation of polypyridyl ligands appears as a potentially appealing design principle to prepare multitargeted $\mathrm{Au}$ (III)-based small molecular drugs that decompose, upon intracellular thiol reduction, into a TrxR inhibitor $\left(\mathrm{Au}^{+}\right.$ions $)$and $\mathrm{K}_{\mathrm{v}} 11.1$ channel inhibitor. However, the reduction kinetics in the medium before drug uptake would need to be better controlled than it is in $[2] \mathrm{Cl}$, for which fast reduction results in high toxicity also to noncancerous cells, resulting in a comparatively low selectivity index.

On the other hand, the rollover cyclometalated complex $[1] \mathrm{Cl}$ is a more promising anticancer compound in several aspects. First, it shows a much higher selectivity index, being as toxic as cisplatin in cancerous cells but almost 10 times less toxic than cisplatin in noncancerous cells. Second, it has a high cellular uptake in cancer cells, which may be due to the formation of nanoparticles in the cell-growing medium, as observed by TEM and DLS. Our preliminary observations are reminiscent of the protein-stabilized aggregation recently described for other molecular drugs such as cisplatin ${ }^{84}$ or experimental palladiumbased cyclometalated compounds. ${ }^{63}$ Third, once inside the cells, the intact $\mathrm{Au}$ (III) complex has excellent redox stability in spite of the high concentration of intracellular thiols, which allows it to distribute in the whole cells. Fourth, the presence of $[1] \mathrm{Cl}$ in the nucleus and in the membrane fractions, together with its ability to both generate single-strand DNA damage and bind to $\mathrm{K}_{\mathrm{v}} 11.1$ potassium channels, suggests at least two possible modes of action explaining anticancer cytotoxicity. Contrary to expectations, this positively charged and hydrophobic gold compound neither inhibits TrxR nor destroys the mitochondrial membrane potential, which distinguishes it from many anticancer $\mathrm{Au}(\mathrm{I})$ compounds and "delocalized lipophilic cations", respectively.

\section{CONCLUSION}

Overall, rollover bis-cyclometalation generates $\mathrm{Au}$ (III) anticancer compounds that offer dramatically different chemical and biological properties compared to analogues bound to pyridyl ligands. In spite of its identical charge and helical molecular shape, $[1] \mathrm{Cl}$ is significantly more hydrophobic and less soluble in water than $[2] \mathrm{Cl}$, leading $[1] \mathrm{Cl}$ to having aggregation properties in aqueous solutions that are not observed for [2] $\mathrm{Cl}$. Critically, the additional electron density brought onto the $\mathrm{Au}(\mathrm{III})$ center by the two carbon ligands in [1] Cl dramatically destabilizes its LUMO compared to [2] Cl, thereby reducing its sensitivity to reduction and rendering its coordination sphere stable in biological media. As a side note, for [2] Cl, the tetradentate binding mode of the $\mathrm{H}_{2}$ biqbpy 2 ligand does not stabilize well enough the coordination sphere of the gold center in biological media, where fast reduction leads to ligand release. Chemically speaking, the redox stabilization brought by rollover cyclometalation in $[1] \mathrm{Cl}$ not only prevents thiol reduction or binding in cell-growing media and inside cells but also generates single-strand DNA damaging properties that are not observed for [2] Cl. Interestingly, the positive charge of both compounds and their similar molecular shape makes them equally good to bind to the poorly selective potassium channel hERG. For [2] Cl, this binding property is biologically poorly relevant, because it would probably be reduced and lose its ligand before coming into contact with any potassium channel. However, for $[1] \mathrm{Cl}$, it is an interesting observation that makes rollover cyclometalation a promising strategy to design $\mathrm{Au}$ (III) anticancer drugs that enter the cell efficiently and inhibit proteins that are different from TxrR.

\section{EXPERIMENTAL SECTION}

\section{Synthesis}

All syntheses were performed in a dinitrogen atmosphere. All the chemical compounds and the other materials were purchased from Sigma-Aldrich. All reactants and solvents were used without further purification. All ${ }^{1} \mathrm{H}$ NMR and ${ }^{13} \mathrm{C}$ attached-proton-test NMR $\left({ }^{13} \mathrm{C}\right.$ APT NMR) spectra were recorded on a Bruker DPX-300 or DMX-400 spectrometer. Chemical shifts are indicated in ppm relative to the residual solvent peak. Electrospray ionization mass spectra (ESI-MS) were recorded by using an MSQ Plus spectrometer in positive ionization mode. High-resolution mass spectra (HRMS) of two palladium complexes were recorded on a Waters XEVO-G2 XSQTOF) mass spectrometer equipped with an electrospray ion source in positive mode (source voltage $3.0 \mathrm{kV}$, desolvation gas flow $900 \mathrm{~L} / \mathrm{h}$, temperature $250{ }^{\circ} \mathrm{C}$ ) with resolution $R=22000$ (mass range $\mathrm{m} / z=$ $50-2000)$ and $200 \mathrm{pg} / \mu \mathrm{L}$ Leu-enkephalin $(\mathrm{m} / z=556.2771)$ as a "lock mass". UV-vis spectra were recorded on a Cary 50 spectrometer from 
Varian. The DFT calculations were carried out using the Amsterdam Density Functional software (ADF2019) from SCM, the PBE0 functional, a triple- $\zeta$ basis set (TZP), and COSMO to simulate the solvents effects in methanol. Human cancer cell lines A549 (human lung carcinoma) and A431 (human skin carcinoma) were purchased from Sigma-Aldrich, distributed by the European Collection of Cell Cultures (ECACC). Dulbecco's modified Eagle's medium (DMEM, with and without phenol red, without glutamine), glutamine-S (GM; $200 \mathrm{~mm}$ ), tris(hydroxylmethyl)aminomethane (Tris base), trichloroacetic acid (TCA), glacial acetic acid, and sulforhodamine B (SRB) were purchased from Sigma-Aldrich. The measurements of the cytotoxicity of the complexes were performed according to the literature. ${ }^{85}$

\section{$\mathrm{H}_{2}$ biqbpy 1}

This ligand was synthesized according to a literature procedure. ${ }^{45} \mathrm{~A}$ mixture of $6,6^{\prime}$-dibromo-2,2'-bipyridine (1004 mg, $3.2 \mathrm{mmol}$ ), $\mathrm{Pd}(\mathrm{dba})_{2}(296 \mathrm{mg}, 0.32 \mathrm{mmol})$, racemic BINAP (395 mg, 0.64 $\mathrm{mmol})$, and cesium carbonate $(4145 \mathrm{mg}, 12.1 \mathrm{mmol})$ was partially dissolved in dry toluene $(50 \mathrm{~mL})$ under $\mathrm{N}_{2}$ atmosphere. The mixture was stirred for $10 \mathrm{~min}$, and then 3 -aminoisoquinoline $(919 \mathrm{mg}, 6.4$ mmol) was added, followed by heating the reaction mixture to $85^{\circ} \mathrm{C}$. After 3 days of stirring, the brown mixture was cooled down. Demi water $(75 \mathrm{~mL})$ was added, and the mixture was stirred for $1 \mathrm{~h}$. The mixture was then filtered and dried under vacuum to obtain the light green product $(1290 \mathrm{mg}, 91 \%$ yield). ESI-MS $\mathrm{m} / z$ (calcd): 441.2 (441.2, $\mathrm{H}_{2}$ biqbpy1 $\left.+\mathrm{H}^{+}\right) .{ }^{1} \mathrm{H}$ NMR $\left(300 \mathrm{MHz}\right.$, DMSO- $\left.d_{6}\right): \delta 10.00(\mathrm{~s}$, $2 \mathrm{H}), 9.13(\mathrm{~s}, 2 \mathrm{H}), 8.80(\mathrm{~s}, 2 \mathrm{H}), 8.08-7.98(\mathrm{~m}, 4 \mathrm{H}), 7.94(\mathrm{t}, J=7.8 \mathrm{~Hz}$, $2 \mathrm{H}), 7.83(\mathrm{t}, J=8.4 \mathrm{~Hz}, 2 \mathrm{H}), 7.67(\mathrm{t}, J=7.4 \mathrm{~Hz}, 2 \mathrm{H}), 7.43(\mathrm{t}, J=7.3 \mathrm{~Hz}$, $2 \mathrm{H}), 7.35(\mathrm{~d}, J=7.9 \mathrm{~Hz}, 2 \mathrm{H})$. Characterization was identical to the reported one. $^{45}$

\section{$\mathrm{H}_{2}$ biqbpy2}

The synthesis of $\mathrm{H}_{2}$ biqbpy2 is similar to that of $\mathrm{H}_{2}$ biqbpy1, except that 2 -aminoquinoline was used to replace 3 -aminoisoquinoline. The yield was $943 \mathrm{mg}, 2.14 \mathrm{mmol}, 67 \%$. ESI-MS $\mathrm{m} / z$ (calcd): 441.2 (441.2, $\mathrm{H}_{2}$ biqbpy $\left.2+\mathrm{H}^{+}\right) .{ }^{1} \mathrm{H}$ NMR (300 MHz, DMSO): $\delta 10.15(\mathrm{~s}, 2 \mathrm{H}), 8.46$ (dd, $J=7.5,1.7 \mathrm{~Hz}, 2 \mathrm{H}), 8.22(\mathrm{~d}, J=9.0 \mathrm{~Hz}, 2 \mathrm{H}), 8.04-7.90(\mathrm{~m}, 4 \mathrm{H})$, $7.80(\mathrm{td}, J=9.1,8.7,1.8 \mathrm{~Hz}, 6 \mathrm{H}), 7.64(\mathrm{ddd}, J=8.4,6.9,1.5 \mathrm{~Hz}, 2 \mathrm{H})$, 7.38 (ddd, $J=8.1,6.9,1.3 \mathrm{~Hz}, 2 \mathrm{H}$ ). Characterization was identical to the reported one. ${ }^{45}$

\section{[Au(biqbpy 1$)] \mathrm{Cl}([1] \mathrm{Cl})$}

A mixture of $\mathrm{H}_{2}$ biqbpyl (100 mg, $0.23 \mathrm{mmol}$ ) and $\mathrm{HAuCl}_{4}(85 \mathrm{mg}$, $0.25 \mathrm{mmol}$ ) was dissolved in $\mathrm{MeOH}(30 \mathrm{~mL})$ and stirred under $\mathrm{N}_{2}$ atmosphere at $75{ }^{\circ} \mathrm{C}$ for 3 days. The solvent was evaporated under reduced pressure and the crude product was purified by column chromatography on silica (DCM-MeOH 10:2, $\left.\mathrm{R}_{\mathrm{f}}=0.35\right)$. Then the complex was dissolved in $\mathrm{MeOH}$ and across the $\mathrm{Cl}^{-}$ion-exchange resin to unify the counterion as $\mathrm{Cl}^{-}$. The yield of final product [1] $\mathrm{Cl}$ was 25 $\mathrm{mg}, 0.03 \mathrm{mmol}, 13 \%$. HRMS $\mathrm{m} / z$ (calcd): $635.1258\left(635.1244,[1]^{+}\right)$. ${ }^{1} \mathrm{H}$ NMR (400 MHz, DMSO- $\left.d_{6}\right): \delta 11.70\left(\mathrm{~s}, 2 \mathrm{H}, \mathrm{H}^{6}\right), 9.08(\mathrm{~d}, J=0.7$ $\left.\mathrm{Hz}, 2 \mathrm{H}, \mathrm{H}^{5}\right), 8.25\left(\mathrm{dd}, J=8.4,7.5 \mathrm{~Hz}, 2 \mathrm{H}, \mathrm{H}^{8}\right), 8.19(\mathrm{dd}, J=7.6,1.1 \mathrm{~Hz}$, $\left.2 \mathrm{H}, \mathrm{H}^{9}\right), 7.87\left(\mathrm{dd}, J=8.4,1.1 \mathrm{~Hz}, 2 \mathrm{H}, \mathrm{H}^{7}\right), 7.78(\mathrm{dt}, J=8.0,1.0 \mathrm{~Hz}, 2 \mathrm{H}$, $\mathrm{H}^{4}$ ), $7.29\left(\mathrm{dd}, J=8.6,1.0 \mathrm{~Hz}, 2 \mathrm{H}, \mathrm{H}^{1}\right), 7.09$ (ddd, $J=8.0,6.8,1.1 \mathrm{~Hz}$, $\left.2 \mathrm{H}, \mathrm{H}^{3}\right), 6.84\left(\mathrm{ddd}, J=8.4,6.9,1.4 \mathrm{~Hz}, 2 \mathrm{H}, \mathrm{H}^{2}\right) .{ }^{13} \mathrm{C} \mathrm{NMR}(101 \mathrm{MHz}$, DMSO- $\left.d_{6}\right): \delta 153.10,151.91,148.04,141.22,140.81,139.21,129.38$, 128.91, 127.24, 126.25, 125.28, 116.34, 115.44, 113.03. Elemental analysis: calcd for [1]Cl $+4 \mathrm{H}_{2} \mathrm{O}$ : C 45.27, $\mathrm{H} 3.53, \mathrm{~N} 11.31$; found $\mathrm{C}$ 45.49, H 3.63, N 11.29.

\section{[Au(biqbpy2)]Cl ([2]Cl)}

A mixture of $\mathrm{H}_{2}$ biqbpy $2(100 \mathrm{mg}, 0.23 \mathrm{mmol})$ and $\mathrm{HAuCl}_{4}(85 \mathrm{mg}$, $0.25 \mathrm{mmol}$ ) was dissolved in $\mathrm{MeOH}(30 \mathrm{~mL})$ and stirred under $\mathrm{N}_{2}$ atmosphere at $75{ }^{\circ} \mathrm{C}$ for $72 \mathrm{~h}$. Then the solvent was rotary evaporated. The solvent was evaporated under reduced pressure and the crude product was purified by column chromatography on silica (DCM$\left.\mathrm{MeOH} 10: 2, \mathrm{R}_{\mathrm{f}}=0.3\right)$. Then the complex was dissolved in $\mathrm{MeOH}$ and across the $\mathrm{Cl}^{-}$ion-exchange resin to unify the counterion as $\mathrm{Cl}^{-}$. The yield of final product [2] Cl was $27 \mathrm{mg}, 0.04 \mathrm{mmol}, 18 \%$. HRMS $\mathrm{m} / z$ (calcd): $635.1258\left(635.1236,[2]^{+}\right) .{ }^{1} \mathrm{H}$ NMR (400 MHz, DMSO- $\left.d_{6}\right)$ : $\delta 8.21\left(\mathrm{dd}, J=8.4,7.4 \mathrm{~Hz}, 2 \mathrm{H}, \mathrm{H}^{8}\right), 8.10\left(\mathrm{dd}, J=7.5,1.3 \mathrm{~Hz}, 2 \mathrm{H}, \mathrm{H}^{7}\right)$, $7.96\left(\mathrm{~d}, J=8.9 \mathrm{~Hz}, 2 \mathrm{H}, \mathrm{H}^{5}\right), 7.63\left(\mathrm{dd}, J=8.4,1.2 \mathrm{~Hz}, 2 \mathrm{H}, \mathrm{H}^{9}\right), 7.59-$ $7.52\left(\mathrm{~m}, 2 \mathrm{H}, \mathrm{H}^{2}\right), 7.41-7.34\left(\mathrm{~m}, 2 \mathrm{H}, \mathrm{H}^{4}\right), 7.28\left(\mathrm{~d}, J=8.9 \mathrm{~Hz}, 2 \mathrm{H}, \mathrm{H}^{6}\right)$, 6.98-6.88 (m, 4H, $\left.\mathrm{H}^{3} . \mathrm{H}^{1}\right) .{ }^{1} \mathrm{H}$ NMR $\left(400 \mathrm{MHz}, \mathrm{D}_{2} \mathrm{O}\right): \delta 7.99(\mathrm{t}, J=$ 8.4, 7.4 Hz, $\left.2 \mathrm{H}, \mathrm{H}^{8}\right), 7.49\left(\mathrm{~d}, J=7.7,1.2 \mathrm{~Hz}, 2 \mathrm{H}, \mathrm{H}^{7}\right), 7.45(\mathrm{~d}, J=8.9$ $\left.\mathrm{Hz}, 2 \mathrm{H}, \mathrm{H}^{6}\right), 7.30\left(\mathrm{~d}, J=8.3,1.1 \mathrm{~Hz}, 2 \mathrm{H}, \mathrm{H}^{9}\right), 6.83\left(\mathrm{~d}, 2 \mathrm{H}, \mathrm{H}^{3}\right), 6.70-$ $6.54\left(\mathrm{~m}, 6 \mathrm{H}, \mathrm{H}^{4}, \mathrm{H}^{5}, \mathrm{H}^{1}\right), 6.47\left(\mathrm{t}, J=7.3 \mathrm{~Hz}, 2 \mathrm{H}, \mathrm{H}^{2}\right) .{ }^{13} \mathrm{C} \mathrm{NMR},(101$ $\left.\mathrm{MHz}, \mathrm{D}_{2} \mathrm{O}\right): 175.78,152.50,149.51,142.01,140.66,139.92,129.11$, $128.65,126.46,125.70,125.57,122.93,118.65,116.89$. Elemental analysis: calcd for [2] Cl $+4 \mathrm{H}_{2} \mathrm{O}$ : C 45.27, $\mathrm{H} 3.53, \mathrm{~N} 11.31$; found $\mathrm{C}$ 45.26, H 3.51, N 11.30.

\section{Solubility Determination}

Excess complex $([1] \mathrm{Cl}$ or $[2] \mathrm{Cl})$ was dissolved in Milli-Q water until precipitate was observed in the solution. Then the solution was centrifuged for $10 \mathrm{~min}$ ( $5000 \mathrm{rpm}$, room temperature). After that, a 5.0 $\mu \mathrm{L}$ sample of the supernatant was taken and diluted to $10.0 \mathrm{~mL}$ with Milli-Q water for ICP-MS measurement. The calculated water solubility for [1] Cl is $0.0064 \mathrm{mg} / \mathrm{mL}$ water, and that for [2] $\mathrm{Cl}$ is 1.45 $\mathrm{mg} / \mathrm{mL}$ water.

\section{Lipophilicity $\left(\log P_{\text {ow }}\right)$ Determination}

The $n$-octanol-saturated water and water-saturated $n$-octanol were prepared using Milli-Q water stirred with $n$-octanol for $24 \mathrm{~h}$. The two layers were separated by centrifugation at $4000 \mathrm{rpm}$ for $5 \mathrm{~min}$. Then the excess of the two gold complexes was dissolved in water-saturated $n$ octanol and heated at $100{ }^{\circ} \mathrm{C}$ for $10 \mathrm{~min}$. After being centrifuged for 5 min at $4000 \mathrm{rpm}$, the supernatant solution was collected. Three aliquots $(50,70,100 \mu \mathrm{L})$ of each stock solution were transferred into six $15 \mathrm{~mL}$ Corning tubes and diluted to $1 \mathrm{~mL}$ with water-saturated $n$-octanol. Then $1 \mathrm{~mL}$ of $n$-octanol-saturated water was added. This mixture was shaken on a GFL 3016 reciprocating shaker at $60 \mathrm{rpm}$ for $24 \mathrm{~h}$. Then all six tubes were centrifuged at $4000 \mathrm{rpm}$ for $5 \mathrm{~min}$ to obtain a clear separation between the two layers in each tube. Next, using a syringe needle, $0.5 \mathrm{~mL}$ aliquots from the aqueous phase were transferred to a new Corning $15 \mathrm{~mL}$ tube, digested using $0.5 \mathrm{~mL}$ of $65 \% \mathrm{HNO}_{3}$, mixed, and then diluted with $9 \mathrm{~mL}$ of Milli-Q water to make total volume to $10.0 \mathrm{~mL}$. A volume of $10 \mu \mathrm{L}$ of each starting stock solution of both complexes was digested by adding $1 \mathrm{~mL}$ of $65 \% \mathrm{HNO}_{3}$ and shaking for $1 \mathrm{~h}$, and then each sample was diluted to $10 \mathrm{~mL}$ by adding Milli-Q water. The gold concentration in the water phase of each biphasic mixture and that of the stock solution were determined by ICP-MS. Partition coefficients $(\log P)$ were calculated using the following formula.

$$
\log P_{\text {oct } / \text { water }}=\log \frac{[\text { complex }]_{\text {total }}-[\text { complex }]_{\text {water }}}{[\text { complex }]_{\text {total }}}
$$

\section{Single Crystal X-ray Crystallography}

The single crystals of $[1] \mathrm{Cl}$ and $[2] \mathrm{AuCl}_{4}$ were obtained by slow evaporation of ether into a saturated $\mathrm{DCM} / \mathrm{MeOH}(5: 1)$ solution of $[1] \mathrm{Cl}$ and $[2] \mathrm{AuCl}_{4}$. All reflection intensities were measured at $110(2)$ $\mathrm{K}$ using a SuperNova diffractometer (equipped with Atlas detector) with either Mo $\mathrm{K} \alpha$ radiation $(\lambda=0.71073 \AA)$ for $[2] \mathrm{AuCl}_{4}$ or $\mathrm{Cu} \mathrm{K} \alpha$ radiation $(\lambda=1.54178 \AA)$ for $[1] \mathrm{Cl}$ under the program CrysAlisPro (version CrysAlisPro 1.171.39.29c, Rigaku OD, 2017). The same program was used to refine the cell dimensions and for data reduction. The two structures were solved with the program SHELXS-2014/7 (Sheldrick, 2015) and were refined on $F^{2}$ with SHELXL-2014/7 (Sheldrick, 2015). For [1] Cl, Analytical numeric absorption correction using a multifaceted crystal model was applied using CrysAlisPro. For [2]AuCl4, numerical absorption correction based on Gaussian integration over a multifaceted crystal model was applied using CrysAlisPro. The temperature of the data collection was controlled using the system Cryojet (manufactured by Oxford Instruments). The CCDC deposition numbers of $[1] \mathrm{Cl}$ and $[2] \mathrm{AuCl}_{4}$ are 2043618 and 2043617, respectively.

Refinement of [1] Cl. The $\mathrm{H}$ atoms were placed at calculated positions using the instructions AFIX 43 with isotropic displacement parameters having the values 1.2 or $1.5 \mathrm{Ueq}$ for the attached $\mathrm{C}$ or $\mathrm{N}$ 
(atoms $\mathrm{N} 2 X$ and N5X, $X=\mathrm{A}, \mathrm{B}, \mathrm{C}, \mathrm{D}, \mathrm{E}$, are protonated as the $\mathrm{N}-\mathrm{C}$ bond distances are consistent with protonation). The $\mathrm{H}$ atoms attached to $\mathrm{O} 1 \mathrm{~W}$ and $\mathrm{O} 2 \mathrm{~W}$ could not be retrieved from the difference Fourier maps (see below for further details). A careful look at the difference Fourier maps near N1X/N6X suggests that no $\mathrm{H}$ atoms are attached to $\mathrm{N} 1 X$ and $\mathrm{N} 6 X(X=\mathrm{A}, \mathrm{B}, \mathrm{C}, \mathrm{D}, \mathrm{E})$. The structure is significantly disordered. Two of the three crystallographically independent Au complexes (Au1 and Au3) are disordered over two orientations, and the occupancy factors of the major components of the disorder refine to 0.649(13) (Au1) and 0.584(4) (Au3). The remaining Au complex (Au2) is ordered. In the final refinement, the counterion $\mathrm{Cl} 3$ is fully occupied, whereas the counterions $\mathrm{Cl} 1, \mathrm{Cl} 2, \mathrm{Cl} 4$, and $\mathrm{Cl} 5$ are found to be partially occupied, and their occupancy factors refine to $0.762(3)$, $0.865(3), 0.202(3)$, and $0.171(2)$, respectively. The sum of the occupancy factors for $\mathrm{Cl} 1 / \mathrm{Cl} 2 / \mathrm{Cl} 4$ and $\mathrm{Cl} 5$ has been constrained to be equal to 2 using the SUMP instruction. Some amount of partially occupied lattice water molecules (O1W and O2W in the asymmetric unit) are found near the sites occupied by $\mathrm{Cl} 4$ and $\mathrm{Cl}$. O1W and $\mathrm{O} 2 \mathrm{~W}$ are most likely lattice water molecules, as the $\mathrm{N} \cdots \mathrm{O} n \mathrm{~W}(n=1,2)$ distances are found within the 2.8-2.9 $\AA$ range. The crystal lattice contains some amount of very disordered lattice solvent molecules. Their contribution has been removed from the final refinement using the SQUEEZE procedure in Platon. ${ }^{86}$

Refinement of [2]AuCl${ }_{4}$. The $\mathrm{H}$ atoms were placed at calculated positions using the instructions AFIX 43 with isotropic displacement parameters having the value 1.2 for the attached $\mathrm{C}$ atoms. The structure is disordered. The Au complex and the $\mathrm{AuCl}_{4}{ }^{-}$counterion are found to be wholly disordered over two orientations. The occupancy factors of the major components of the disorder refine to $0.651(10)$ and $0.735(16)$. The crystal was found to be twinned, and the general twin relationship corresponds to a 2 -fold axis along the $c^{*}$ direction as the true monoclinic cell emulates an orthorhombic cell with a $\beta$ angle close to $90^{\circ}$. In the final refinement, general and racemic twinning were

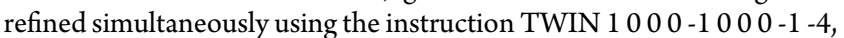
and the three BASF scale factors refine to $0.010(6), 0.36(6)$, and $0.18(6)$.

\section{DFT Calculation}

$[1]^{+}$and $[2]^{+}$were minimized by DFT at the PBE0/TZP level of theory using scalar relativity effects and COSMO in water to simulate solvent effects, as implemented in the ADF2019 program from SCM, ${ }^{87}$ starting from the coordinates obtained in the crystal structures. The 20 first Franck-Condon singlet-singlet transitions were calculated by TDDFT at the same level of theory, using the Davidson method and the DFT-minimized geometries.

\section{Cytotoxicity}

Cell culture and cytotoxicity measurements were performed according to previously published methods. ${ }^{85}$ In short: A549, A375, MCF7, or MRC5 cells were seeded at $t=0$ in 96-well plates at a density of 5000, 7000, 8000, and 6000 cells/well $(100 \mu \mathrm{L})$, respectively, in OptiMEM supplemented with $2.4 \% \mathrm{v} / \mathrm{v}$ FCS, $0.2 \% \mathrm{v} / \mathrm{v} \mathrm{P} / \mathrm{S}$, and $1.0 \% \mathrm{v} / \mathrm{v} \mathrm{GM}$ (called OptiMEM complete) and incubated for $24 \mathrm{~h}$ at $37^{\circ} \mathrm{C}$ and $7.0 \%$ $\mathrm{CO}_{2}$. At $t=24 \mathrm{~h}$, aliquots $(100 \mu \mathrm{L})$ of six different concentrations of freshly prepared stock solutions of the compounds in OptiMEM complete were added to the wells in triplicate and incubated for $72 \mathrm{~h}$. Sterilized dimethylsulfoxide (DMSO) was used to prepare stock solution of the compounds, in such amounts that the maximum $\mathrm{v} / \mathrm{v} \%$ of DMSO per well did not exceed $0.5 \%$. At $t=96 \mathrm{~h}$, the cells were fixated by adding cold TCA $(10 \% \mathrm{w} / \mathrm{v} ; 100 \mu \mathrm{L})$ in each well and the plates were stored at $4{ }^{\circ} \mathrm{C}$ for at least $4 \mathrm{~h}$ as part of the SRB assay that was adapted from Vichai and Kirtikara. ${ }^{88}$ In short, after fixation, the TCA medium mixture was removed from the wells and the wells were rinsed with demineralized water three times. Next, each well was stained with $100 \mu \mathrm{L}$ of SRB $(0.6 \% \mathrm{w} / \mathrm{v}$ in $1 \% \mathrm{v} / \mathrm{v}$ acetic acid) for $30 \mathrm{~min}$. The SRB was removed by washing with acetic acid $(1 \% \mathrm{v} / \mathrm{v})$ and the plate was airdried. The SRB dye was solubilized with Tris base $(10 \mathrm{mM} ; 200 \mu \mathrm{L})$ overnight, and the absorbance in each well was read at $\lambda=510 \mathrm{~nm}$.

\section{ICP-MS Analysis}

Materials. Nitric acid (65\%, Suprapur, Merck) was used in the sample digestion process, while diluted nitric acid $(1 \%, \mathrm{v} / \mathrm{v})$ was used as a carrying solution throughout the ICP measurements. National Institute of Standards and Technology (NIST)-traceable $1000 \mathrm{mg} / \mathrm{L}$ elemental standards were used (TraceCERT, Fluka) for preparation of calibration and internal standards. Approximately $18 \mathrm{M} \Omega \mathrm{cm}^{-1}$ water (Milli-Q) was used in all sample preparation and analysis steps.

Instrumentation. Calibration standards were prepared in a Secuflow fume hood (SCALA) to prevent contamination by atmospheric particulates. The standard samples and measurement samples were analyzed for trace elements using the NexION 2000 (PerkinElmer) ICP-MS instrument equipped with a concentric glass nebulizer and Peltier-cooled glass spray chamber. An SC2 DX autosampler (PerkinElmer) was connected to the ICP-MS for sample introduction. Syngistix software for ICP-MS (v.2.5, PerkinElmer) was used for all data recording and processing. Five trace elemental calibration standards for ICP-MS analysis were prepared using NISTtraceable $1000 \mathrm{mg} / \mathrm{L}$ Au standards: 0, 1, 5, 20, and $100 \mu \mathrm{g} / \mathrm{L}$. Samples were analyzed without dilution in the original delivery containers to minimize the possibility of contamination. Here, $10 \mu \mathrm{g} / \mathrm{L} \mathrm{Rh}$ and In were used as internal standards. To check the calibration, samples were analyzed with a blank measurement and a repeat measurement of one of the calibration standards. For the calibration curve, the accepted correlation coefficient (Cor.Coeff) was to be found higher than 0.999 .

\section{Gold Cellular Uptake}

A549 cells were seeded in a 12 -well plate $\left(2 \times 10^{5}\right.$ cells, $1 \mathrm{~mL}$ of OptiMEM complete per well). At $t=24 \mathrm{~h}$, the cells were treated with complexes [1] Cl or [2] Cl ( $1 \mu \mathrm{M}, 1 \mathrm{~mL}$ Opti-MEM complete). After 24 $\mathrm{h}$ treatment, the cells were washed with PBS $(1 \mathrm{~mL})$ three times, harvested by trypsinzation ( $5 \% \mathrm{v} / \mathrm{v}$ in PBS), counted with trypan blue on a TC20 automated cell counter, and centrifuged in $15 \mathrm{~mL}$ tubes. After removing the supernatant, the cell pellets were lysed by adding 0.5 $\mathrm{mL}$ of $\mathrm{HNO}_{3}(65 \%)$ into the tubes and shaking for $24 \mathrm{~h}$. After that, the cell solution was diluted to $10 \mathrm{~mL}$ using Milli-Q water, and the $\mathrm{Au}$ content in the solution was determined by ICP-MS (NexION 2000, PerkinElmer) according to the protocol described above. The final results are the mean of three independent experiments.

\section{Cellular Uptake Inhibition}

A549 cells were seeded in two 12 -well plates $\left(5 \times 10^{5}\right.$ cells, $1 \mathrm{~mL}$ of Opti-MEM complete per well) and labeled as 4 and $37^{\circ} \mathrm{C}$ groups, respectively. At $t=23.5 \mathrm{~h}$, the cells in the $4{ }^{\circ} \mathrm{C}$ group were cooled to 4 ${ }^{\circ} \mathrm{C}$ for $30 \mathrm{~min}$. At $t=24 \mathrm{~h}$, the cells in the 4 and $37{ }^{\circ} \mathrm{C}$ groups were treated with [1] Cl or [2] Cl (5 $\mu \mathrm{M}, 1 \mathrm{~mL}$ of Opti-MEM complete $)$ and incubated at the set temperature for another $2 \mathrm{~h}$. Then the same procedure as that described above was used to for the ICP-MS sample preparation and measurement. The final results are the mean of three independent experiments.

\section{Cell Fractionation and Localization of Gold}

A549 cells were seeded into $10 \mathrm{~cm}$ dishes $\left(5 \times 10^{5}\right.$ cells, $10 \mathrm{~mL}$ of OptiMEM completed) and incubated in normoxic conditions for 3 days. Then the cells were treated with $[1] \mathrm{Cl}$ or $[2] \mathrm{Cl}(1 \mu \mathrm{M}, 10 \mathrm{~mL}$ of OptiMEM complete) for another $24 \mathrm{~h}$. After that, the medium was removed and cells were washed three times with PBS and harvested by trypsinization. The cell pellets were collected after $3 \mathrm{~min}$ of centrifugation $(2000 \mathrm{rpm})$ and removing the supernatant. Then the cell pellets were fractionated to collect the cytosol, membrane, nucleus, and cytoskeletal fractions using the fractionPREP cell fractionation kit from BioVision according to the instructions of the supplier. Then each fraction solution was acidified by adding $0.5 \mathrm{~mL}$ of $65 \% \mathrm{HNO}_{3}$ and shaking at room temperature for $24 \mathrm{~h}$. After that, the membrane fractions were treated with $0.5 \mathrm{~mL}$ of $30 \% \mathrm{H}_{2} \mathrm{O}_{2}$ and heated at $90{ }^{\circ} \mathrm{C}$ in an oven for $24 \mathrm{~h}$ to dissolve all biological materials. Then the Au content in each fraction was measured using ICP-MS. The final gold content was averaged from three replicate experiments; values are reported in Table S8 and Figure S11. 


\section{Mitochondrial Potential Determination}

A549 cells were seeded in to 12 well plates $\left(1 \times 10^{5}\right.$ cells, $\left.1 \mathrm{~mL}\right)$ and incubated for $24 \mathrm{~h}$ in normoxic conditions. After that the cells were treated with [1] Cl or [2] Cl $(20 \mu \mathrm{M})$ and incubated for another $24 \mathrm{~h}$. Then the cells were washed with PBS one time and stained with TRME $(150 \mathrm{nM})$ for $30 \mathrm{~min}$. The cells in the positive group were treated with CCCP $(20 \mu \mathrm{M})$ for $1 \mathrm{~h}$ prior to the treatment with TRME. The cells were harvested, and then the emission of TRME in cells was detected by flow cytometry using the yellow-blue channel (488 excitation, 575 emission).

\section{DNA Gel Electrophoresis}

The pUC19 plasmid used for this study (2686 bp) exists in three forms: supercoiled (SC), single-nicked open circular (OC), and linear dimer (LD). If the metal complexes can cleave DNA single strands, the proportion of the SC part will decrease while that of OC will increase; if the complex does cleave double stranded DNA, then the LD proportion increases at the cost of the other bands. Agarose gel electrophoresis was used to evaluate the DNA cleavage properties of [1] $\mathrm{Cl}$ and $[2] \mathrm{Cl}$ in different base pair/metal complex ratios (BP:MC). Two buffers were used for the experiments: $5 \times$ tris-boric acid buffer (TBA) and phosphate buffer (PB). The $5 \times$ tris-boric acid (TBA) buffer $(45 \mathrm{mM}$ tris(hydroxymethyl)aminomethane and $45 \mathrm{mM}$ boric acid, $\mathrm{pH}=7.4$ ) was used as the gel and running buffer. Phosphate buffer (PB, $100 \mathrm{mM}$ $\mathrm{NaH}_{2} \mathrm{PO}_{4}, \mathrm{pH}=7.0$ ) was used for DNA-MC interactions. The molar concentration of the pUC19 plasmid DNA base pairs (BPs) was determined using the extinction coefficient $\left(\varepsilon_{260 \mathrm{~nm}}=13200\right.$ $\left.\mathrm{M}^{-1} \mathrm{~cm}^{-1}\right) .{ }^{89}$

Agarose gel electrophoresis was used to assay the thermal and photoinduced binding of $[1] \mathrm{Cl}$ and $[2] \mathrm{Cl}$ to pUC19 plasmid DNA. The agarose gels were $0.8 \% \mathrm{w} / \mathrm{w}$ agarose gel $(0.24 \mathrm{~g}$ agarose, $24 \mathrm{~g}$ of DI $\mathrm{H}_{2} \mathrm{O}$, and $6 \mathrm{~mL}$ of TBA). Two buffers were used for the experiments: $5 \times$ TBA and PB. The $5 \times$ TBA buffer ( $45 \mathrm{mM}$ tris(hydroxymethyl)amino methane and $45 \mathrm{mM}$ boric acid, $\mathrm{pH}=7.4)$ was used as the gel and running buffer. $\mathrm{PB}\left(100 \mathrm{mM} \mathrm{NaH} \mathrm{PO}_{4}, \mathrm{pH}=7.0\right)$ was used for DNA--MC interactions. Before starting the gel electrophoresis, the electrophoresis chamber was filled with $50 \mathrm{~mL}$ of TBA and $210 \mathrm{~mL}$ of deionized water (running buffer).

The contents of each lane in the gel were set according to Table S9. After incubation with the gold complexes or cisplatin for $24 \mathrm{~h}$ at $37{ }^{\circ} \mathrm{C}$, $12 \mu \mathrm{L}$ of each samples was transferred to the gel and the gel was run at a constant voltage of $105 \mathrm{~V}$ for $90 \mathrm{~min}$. The gel was stained using $10 \mu \mathrm{L}$ $(10 \mathrm{mg} / \mathrm{mL})$ of ethidium bromide in $200 \mathrm{~mL}$ of deionized water for 30 min with slight shaking and then destained in $200 \mathrm{~mL}$ of deionized water for $20 \mathrm{~min}$. Immediately following destaining, the gel was imaged using a BioRad ChemiDoc imaging system (ethidium bromide setting). Image Lab software was used to process the images.

\section{TrxR Inhibition Property Determination}

To determine the inhibition of mammalian thioredoxin reductase (TrxR), a spectrophotometric assay was done using commercially available rat liver TrxR (Sigma-Aldrich). The enzyme was diluted with distilled water to achieve a concentration of $2.5 \mathrm{U} / \mathrm{mL}$. The gold complexes were freshly dissolved in DMF to get a stock solution of 10 $\mathrm{mM}$. To a $25 \mu \mathrm{L}$ aliquot of the enzyme solution, $25 \mu \mathrm{L}$ of potassium phosphate buffer, $\mathrm{pH} 7.0$, containing the complexes at different concentrations or vehicle (DMF) without compounds (control probe) was added, and the resulting solutions (final concentration of DMF: max. $0.5 \% \mathrm{v} / \mathrm{v}$ ) were incubated with moderate shaking for $75 \mathrm{~min}$ at 37 ${ }^{\circ} \mathrm{C}$ in a 96-well plate. Subsequently, to each well, $225 \mu \mathrm{L}$ of the reaction mixture $(1000 \mu \mathrm{L}$ of reaction mixture consisted of $500 \mu \mathrm{L}$ of potassium phosphate buffer, $\mathrm{pH} 7.0,80 \mu \mathrm{L}$ of EDTA solution ( $100 \mathrm{mM}, \mathrm{pH} 7.5)$, $20 \mu \mathrm{L}$ of BSA solution (0.2\%), $100 \mu \mathrm{L}$ of NADPH solution $(20 \mathrm{mM})$, and $300 \mu \mathrm{L}$ of distilled water) was added. The reaction was started by the addition of $25 \mu \mathrm{L}$ of an ethanolic 5,5'-dithiobis 2-nitrobenzoic solution (DTNB, $20 \mathrm{mM}$ ). After proper mixing, the formation of 5TNB was monitored with a microplate reader (PerkinElmer Victor X4) at $405 \mathrm{~nm}$ in $10 \mathrm{~s}$ intervals for $10 \mathrm{~min}$. The increase in 5-TNB concentration over time followed a linear trend $\left(R^{2} \geq 0.99\right)$, and the enzymatic activities were calculated as the slopes (increase in absorbance per second) thereof. For each tested compound, the noninterference with the assay components was confirmed by a negative control experiment using an enzyme-free solution. The $\mathrm{IC}_{50}$ values were calculated as the concentration of complexes decreasing the enzymatic activity of the untreated control by $50 \%$ and are given as the means and standard deviations of two independent experiments.

\section{$\mathrm{K}_{\mathrm{v}}$ 11.1 Potassium Channel Binding Affinity}

This experiment was carried out according to a literature procedure. ${ }^{80}$ Briefly, the cell membranes of HEK293 Kv 11.1 cells were collected. Then the loading of $\left[{ }^{3} \mathrm{H}\right]$ astemizole on the cell membranes was performed by mixing membrane aliquots containing $30 \mu \mathrm{g}$ of protein with $2 \mathrm{nM}\left[{ }^{3} \mathrm{H}\right]$ dofetilide in a total volume of $100 \mu \mathrm{L}$ of incubation buffer at $15{ }^{\circ} \mathrm{C}$ for $90 \mathrm{~min}$. After loading, a single point dissociation assay was initiated by the addition of $10 \mu \mathrm{M}$ dofetilide in the absence (control) or presence of $10 \mu \mathrm{M}$ of gold complexes and corresponding ligands. After $10 \mathrm{~min}$ of incubation, samples were separated by rapid filtration through a 96-well GF/B filter plate using a PerkinElmer Filtermate harvester (PerkinElmer, Groningen, The Netherlands). Filters were subsequently washed with ice-cold wash buffer two times. Then the filter-bound radioactivity was determined by scintillation spectrometry by using the 1450 Microbeta Wallac Trilux scintillation counter (PerkinElmer) after the addition of $37.5 \mu \mathrm{L}$ of Microscint and for another $2 \mathrm{~h}$ extraction. The binding of $\left[{ }^{3} \mathrm{H}\right]$ dofetilide in the control was set as $100 \%$.

\section{ASSOCIATED CONTENT}

\section{Supporting Information}

The Supporting Information is available free of charge at https://pubs.acs.org/doi/10.1021/jacsau.0c00104.

Atom numbering scheme for ${ }^{1} \mathrm{H}$ NMR interpretation; crystallographic data for $[1] \mathrm{Cl}$ and $[2] \mathrm{AuCl}_{4} ;{ }^{1} \mathrm{H} \mathrm{NMR}$ spectra of $[1] \mathrm{Cl}$ in DMSO: $\mathrm{H}_{2} \mathrm{O}$ mixtures; $x, y, z$ coordinates of the DFT-minimized geometries and details of the TDDFT-calculated singlet-singlet transitions; spectra during stability measurements; TEM images; dose-response curves of the cytotoxicity measurements; ICP-MS results; FACS data; DNA gel electrophoresis data; tumor spheroid images (PDF)

Crystallographic data for $[1] \mathrm{Cl}$ (CIF)

Crystallographic data for $[2]\left(\mathrm{AuCl}_{4}\right)(\mathrm{CIF})$

\section{AUTHOR INFORMATION}

\section{Corresponding Author}

Sylvestre Bonnet - Leiden Institute of Chemistry, Leiden University, 2333 CC Leiden, The Netherlands; 이이.org/ 0000-0002-5810-3657; Email: bonnet@

chem.leidenuniv.nl

\section{Authors}

Xue-Quan Zhou - Leiden Institute of Chemistry, Leiden University, 2333 CC Leiden, The Netherlands

Imma Carbo-Bague - Leiden Institute of Chemistry, Leiden University, 2333 CC Leiden, The Netherlands; Department of Chemistry, Simon Fraser University, Burnaby, British Columbia V5A 1S6, Canada

Maxime A. Siegler - Department of Chemistry, Johns Hopkins University, Baltimore, Maryland 21218, United States; (1) orcid.org/0000-0003-4165-7810

Jonathan Hilgendorf - Leiden Institute of Chemistry, Leiden University, 2333 CC Leiden, The Netherlands

Uttara Basu - Institute of Medicinal and Pharmaceutical Chemistry, Technische Universität Braunschweig, 38106 Braunschweig, Germany 
Ingo Ott - Institute of Medicinal and Pharmaceutical Chemistry, Technische Universität Braunschweig, 38106 Braunschweig, Germany

Rongfang Liu - Division of Drug Discovery \& Safety, Leiden Academic Centre for Drug Research, Leiden University, 2333 CC Leiden, The Netherlands

Liyan Zhang - Leiden Institute of Chemistry, Leiden University, 2333 CC Leiden, The Netherlands

Vadde Ramu - Leiden Institute of Chemistry, Leiden University, 2333 CC Leiden, The Netherlands

Adriaan P. IJzerman - Division of Drug Discovery \& Safety, Leiden Academic Centre for Drug Research, Leiden University, 2333 CC Leiden, The Netherlands; 이이이.org/0000-00021182-2259

Complete contact information is available at:

https://pubs.acs.org/10.1021/jacsau.0c00104

Notes

The authors declare no competing financial interest.

\section{ACKNOWLEDGMENTS}

X.-Q.Z. gratefully acknowledges the China Scholarship Council (CSC) for a personal grant (No. 201606200045). This work is supported by the European Research Council via a Starting Grant to S.B. Dr. S. Zheng is thanked for ICP-MS measurement. Prof. E. Bouwman is wholeheartedly acknowledged for scientific discussion and support.

\section{REFERENCES}

(1) Muggia, F. M.; Bonetti, A.; Hoeschele, J. D.; Rozencweig, M.; Howell, S. B. Platinum antitumor complexes: 50 years since Barnett Rosenberg's discovery. J. Clin. Oncol. 2015, 33, 4219-4226.

(2) Liu, Y. R.; Ji, C.; Zhang, H. Y.; Dou, S. X.; Xie, P.; Wang, W. C.; Wang, P. Y. Transplatin enhances effect of cisplatin on both single DNA molecules and live tumor cells. Arch. Biochem. Biophys. 2013, 536 (1), $12-24$.

(3) Nafisi, S.; Norouzi, Z. A comparative study on the interaction of cis-and trans-platin with DNA and RNA. DNA Cell Biol. 2009, 28 (9), 469-477.

(4) Pandrala, M.; Sundaraneedi, M. K.; Ammit, A. J.; Woodward, C. E.; Wallace, L.; Keene, F. R.; Collins, J. G. Differential Anticancer Activities of the Geometric Isomers of Dinuclear Iridium(III) Complexes. Eur. J. Inorg. Chem. 2015, 2015, 5694-5701.

(5) Meier-Menches, S. M.; Gerner, C.; Berger, W.; Hartinger, C. G.; Keppler, B. K. Structure-activity relationships for ruthenium and osmium anticancer agents - towards clinical development. Chem. Soc. Rev. 2018, 47 (3), 909-928.

(6) Thota, S.; Rodrigues, D. A.; Crans, D. C.; Barreiro, E. J. Ru(II) Compounds: Next-Generation Anticancer Metallotherapeutics? J. Med. Chem. 2018, 61 (14), 5805-5821.

(7) Lazarević, T.; Rilak, A.; Bugarčić, Ž. D. Platinum, palladium, gold and ruthenium complexes as anticancer agents: Current clinical uses, cytotoxicity studies and future perspectives. Eur. J. Med. Chem. 2017, $142,8-31$.

(8) Cutillas, N.; Yellol, G. S.; de Haro, C.; Vicente, C.; Rodríguez, V.; Ruiz, J. Anticancer cyclometalated complexes of platinum group metals and gold. Coord. Chem. Rev. 2013, 257 (19-20), 2784-2797.

(9) Yan, J. J.; Chow, A. L.; Leung, C. H.; Sun, R. W.; Ma, D. L.; Che, C. M. Cyclometalated gold(III) complexes with N-heterocyclic carbene ligands as topoisomerase I poisons. Chem. Commun. 2010, 46 (22), 3893-5.

(10) Massai, L.; Zoppi, C.; Cirri, D.; Pratesi, A.; Messori, L. Reactions of Medicinal Gold(III) Compounds With Proteins and Peptides Explored by Electrospray Ionization Mass Spectrometry and Complementary Biophysical Methods. Front. Chem. 2020, 8, 581648.
(11) Mora, M.; Gimeno, M. C.; Visbal, R. Recent advances in goldNHC complexes with biological properties. Chem. Soc. Rev. 2019, 48 (2), 447-462.

(12) Zou, T.; Lum, C. T.; Lok, C.-N.; Zhang, J.-J.; Che, C.-M. Chemical biology of anticancer gold(iii) and gold(i) complexes. Chem. Soc. Rev. 2015, 44 (24), 8786-8801.

(13) Jurgens, S.; Kuhn, F. E.; Casini, A. Cyclometalated Complexes of Platinum and Gold with Biological Properties: State-of-the-Art and Future Perspectives. Curr. Med. Chem. 2018, 25 (4), 437-461.

(14) Bindoli, A.; Rigobello, M. P.; Scutari, G.; Gabbiani, C.; Casini, A.; Messori, L. Thioredoxin reductase: A target for gold compounds acting as potential anticancer drugs. Coord. Chem. Rev. 2009, 253 (11), 16921707.

(15) Jia, J.-J.; Geng, W.-S.; Wang, Z.-Q.; Chen, L.; Zeng, X.-S. The role of thioredoxin system in cancer: strategy for cancer therapy. Cancer Chemother. Pharmacol. 2019, 84 (3), 453-470.

(16) Gamcsik, M. P.; Kasibhatla, M. S.; Teeter, S. D.; Colvin, O. M. Glutathione levels in human tumors. Biomarkers 2012, 17 (8), 671691.

(17) Biaglow, J. E.; Miller, R. A. The thioredoxin reductase/ thioredoxin system: Novel redox targets for cancer therapy. Cancer Biol. Ther. 2005, 4 (1), 13-20.

(18) Nguyen, P.; Awwad, R. T.; Smart, D. D. K.; Spitz, D. R.; Gius, D. Thioredoxin reductase as a novel molecular target for cancer therapy. Cancer Lett. 2006, 236 (2), 164-174.

(19) Furst, D. E. Mechanism of Action, Pharmacology, Clinical Efficacy and Side Effects of Auranofin: An Orally Administered Organic Gold Compound for the Treatment of Rheumatoid Arthritis. Pharmacotherapy 1983, 3 (5), 284-296.

(20) Angelucci, F.; Sayed, A. A.; Williams, D. L.; Boumis, G.; Brunori, M.; Dimastrogiovanni, D.; Miele, A. E.; Pauly, F.; Bellelli, A. Inhibition ofSchistosoma mansoniThioredoxin-glutathione Reductase by Auranofin. J. Biol. Chem. 2009, 284 (42), 28977-28985.

(21) Onodera, T.; Momose, I.; Kawada, M. Potential Anticancer Activity of Auranofin. Chem. Pharm. Bull. 2019, 67 (3), 186-191.

(22) Shi, P.; Jiang, Q.; Lin, J.; Zhao, Y.; Lin, L.; Guo, Z. Gold(III) compounds of 1,4,7-triazacyclononane showing high cytotoxicity against A-549 and HCT-116 tumor cell lines. J. Inorg. Biochem. 2006, 100 (5), 939-945.

(23) Ott, I. On the medicinal chemistry of gold complexes as anticancer drugs. Coord. Chem. Rev. 2009, 253 (11-12), 1670-1681.

(24) Lum, C. T.; Wong, A. S.; Lin, M. C.; Che, C. M.; Sun, R. W. A gold(III) porphyrin complex as an anti-cancer candidate to inhibit growth of cancer-stem cells. Chem. Commun. 2013, 49 (39), 4364-6.

(25) Sun, R. W.-Y.; Lok, C.-N.; Fong, T. T.-H.; Li, C. K.-L.; Yang, Z. F.; Zou, T.; Siu, A. F.-M.; Che, C.-M. A dinuclear cyclometalated gold(iii) - phosphine complex targeting thioredoxin reductase inhibits hepatocellular carcinoma in vivo. Chem. Sci. 2013, 4, 1979-1988.

(26) Jurgens, S.; Scalcon, V.; Estrada-Ortiz, N.; Folda, A.; Tonolo, F.; Jandl, C.; Browne, D. L.; Rigobello, M. P.; Kuhn, F. E.; Casini, A. Exploring the $\mathrm{C} \wedge \mathrm{N} \wedge \mathrm{C}$ theme: Synthesis and biological properties of tridentate cyclometalated gold(III) complexes. Bioorg. Med. Chem. 2017, 25 (20), 5452-5460.

(27) Śmiłowicz, D.; Slootweg, J. C.; Metzler-Nolte, N. Bioconjugation of Cyclometalated Gold(III) Lipoic Acid Fragments to Linear and Cyclic Breast Cancer Targeting Peptides. Mol. Pharmaceutics 2019, 16 (11), 4572-4581.

(28) Bondžić, A. M.; Janjić, G. V.; Dramićanin, M. D.; Messori, L.; Massai, L.; Parac Vogt, T. N.; Vasić, V. M. Na/K-ATPase as a target for anticancer metal based drugs: insights into molecular interactions with selected gold(iii) complexes. Metallomics 2017, 9 (3), 292-300.

(29) Marzo, T.; Scaletti, F.; Michelucci, E.; Gabbiani, C.; Pescitelli, G.; Messori, L.; Massai, L. Interactions of the organogold(III) compound Aubipyc with the copper chaperone Atox1: a joint mass spectrometry and circular dichroism investigation. BioMetals 2015, 28 (6), 10791085.

(30) Köster, S. D.; Alborzinia, H.; Can, S.; Kitanovic, I.; Wölfl, S.; Rubbiani, R.; Ott, I.; Riesterer, P.; Prokop, A.; Merz, K.; Metzler-Nolte, $\mathrm{N}$. A spontaneous gold(i)-azide alkyne cycloaddition reaction yields 
gold-peptide bioconjugates which overcome cisplatin resistance in a p53-mutant cancer cell line. Chem. Sci. 2012, 3 (6), 2062-2072.

(31) Wang, X.; Guo, Z. Towards the rational design of platinum(ii) and gold(iii) complexes as antitumour agents. Dalton Trans. 2008, No. 12, 1521-1532.

(32) Yang, T.; Tu, C.; Zhang, J.; Lin, L.; Zhang, X.; Liu, Q.; Ding, J.; $\mathrm{Xu}, \mathrm{Q}$; Guo, Z. Novel $\mathrm{Au}$ (iii) complexes of aminoquinoline derivatives: crystal structure, DNA binding and cytotoxicity against melanoma and lung tumour cells. Dalton Trans. 2003, No. 17, 3419-3424.

(33) Pratesi, A.; Cirri, D.; Fregona, D.; Ferraro, G.; Giorgio, A.; Merlino, A.; Messori, L. Structural Characterization of a Gold/Serum Albumin Complex. Inorg. Chem. 2019, 58 (16), 10616-10619.

(34) Kumar, R.; Nevado, C. Cyclometalated Gold(III) Complexes: Synthesis, Reactivity, and Physicochemical Properties. Angew. Chem., Int. Ed. 2017, 56 (8), 1994-2015.

(35) Tang, M.-C.; Li, L.-K.; Lai, S.-L.; Cheung, W.-L.; Ng, M.; Wong, C.-Y.; Chan, M.-Y.; Yam, V. W.-W. Design Strategy Towards Horizontally Oriented Luminescent Tetradentate-Ligand-Containing Gold(III) Systems. Angew. Chem., Int. Ed. 2020, 59 (47), 2102321031.

(36) Zhou, D.; To, W.-P.; Tong, G. S. M.; Cheng, G.; Du, L.; Phillips, D. L.; Che, C.-M. Tetradentate Gold(III) Complexes as Thermally Activated Delayed Fluorescence (TADF) Emitters: MicrowaveAssisted Synthesis and High-Performance OLEDs with Long Operational Lifetime. Angew. Chem., Int. Ed. 2020, 59 (16), 6375-6382.

(37) Butschke, B.; Schwarz, H. Rollover" cyclometalation - early history, recent developments, mechanistic insights and application aspects. Chem. Sci. 2012, 3 (2), 308-326.

(38) Leist, M.; Kerner, C.; Ghoochany, L. T.; Farsadpour, S.; Fizia, A.; Neu, J. P.; Schön, F.; Sun, Y.; Oelkers, B.; Lang, J.; Menges, F.; NiednerSchatteburg, G.; Salih, K. S. M.; Thiel, W. R. Roll-over cyclometalation: A versatile tool to enhance the catalytic activity of transition metal complexes. J. Organomet. Chem. 2018, 863, 30-43.

(39) Zucca, A.; Petretto, G. L.; Stoccoro, S.; Cinellu, M. A.; Manassero, M.; Manassero, C.; Minghetti, G. Cyclometalation of 2, 2'Bipyridine. Mono-and Dinuclear C, N Platinum (II) Derivatives. Organometallics 2009, 28 (7), 2150-2159.

(40) Maidich, L.; Dettori, G.; Stoccoro, S.; Cinellu, M. A.; Rourke, J. P.; Zucca, A. Electronic and Steric Effects in Rollover $\mathrm{C}-\mathrm{H}$ Bond Activation. Organometallics 2015, 34 (5), 817-828.

(41) Babak, M. V.; Pfaffeneder-Kmen, M.; Meier-Menches, S. M.; Legina, M. S.; Theiner, S.; Licona, C.; Orvain, C.; Hejl, M.; Hanif, M.; Jakupec, M. A.; Keppler, B. K.; Gaiddon, C.; Hartinger, C. G. Rollover Cyclometalated Bipyridine Platinum Complexes as Potent Anticancer Agents: Impact of the Ancillary Ligands on the Mode of Action. Inorg. Chem. 2018, 57 (5), 2851-2864.

(42) Maidich, L.; Cinellu, M. A.; Cocco, F.; Stoccoro, S.; Sedda, M.; Galli, S.; Zucca, A. Platinum(II), palladium(II) and gold(III) adducts and cyclometalated derivatives of 6-methoxy-2,2'-bipyridine: A comparative study. J. Organomet. Chem. 2016, 819, 76-86.

(43) Cocco, F.; Cinellu, M. A.; Minghetti, G.; Zucca, A.; Stoccoro, S.; Maiore, L.; Manassero, M. Intramolecular C(sp2)-H Bond Activation in 6,6'-Dimethoxy-2,2'-Bipyridine with Gold(III). Crystal and Molecular Structure of the First $\mathrm{N}^{\prime}, \mathrm{C}(3)$ "Rollover" Cycloaurated Derivative. Organometallics 2010, 29 (5), 1064-1066.

(44) Meier, S. M.; Gerner, C.; Keppler, B. K.; Cinellu, M. A.; Casini, A. Mass Spectrometry Uncovers Molecular Reactivities of Coordination and Organometallic Gold(III) Drug Candidates in Competitive Experiments That Correlate with Their Biological Effects. Inorg. Chem. 2016, 55 (9), 4248-59.

(45) van Rixel, V. H. S.; Siewert, B.; Hopkins, S. L.; Askes, S. H. C.; Busemann, A.; Siegler, M. A.; Bonnet, S. Green light-induced apoptosis in cancer cells by a tetrapyridyl ruthenium prodrug offering two trans coordination sites. Chem. Sci. 2016, 7 (8), 4922-4929.

(46) Simonov, Y.; Bologa, O.; Bourosh, P.; Gerbeleu, N.; Lipkowski, J.; Gdaniec, M. Synthesis and structural characterization of gold(III) dioximates with anions $[\mathrm{AuCl} 4]-$ and $[\mathrm{AuCl} 2]-$. Inorg. Chim. Acta 2006, 359 (2), 721-725.
(47) Janiak, C. A critical account on $\pi-\pi$ stacking in metal complexes with aromatic nitrogen-containing ligands. Dalton Trans. 2000, 21 (21), $3885-3896$.

(48) Nakakuki, Y.; Hirose, T.; Matsuda, K. Synthesis of a Helical Analogue of Kekulene: A Flexible pi-Expanded Helicene with Large Helical Diameter Acting as a Soft Molecular Spring. J. Am. Chem. Soc. 2018, 140 (45), 15461-15469.

(49) Saleh, N.; Shen, C.; Crassous, J. Helicene-based transition metal complexes: synthesis, properties and applications. Chem. Sci. 2014, 5 (10), 3680-3694.

(50) Kramer, R.; Lehn, J. M.; Marquis-Rigault, A. Self-recognition in helicate self-assembly: spontaneous formation of helical metal complexes from mixtures of ligands and metal ions. Proc. Natl. Acad. Sci. U. S. A. 1993, 90 (12), 5394-5398.

(51) Zarges, W.; Hall, J.; Lehn, J.-M.; Bolm, C. Helicity Induction in Helicate Self-Organisation from Chiral Tris(bipyridine) Ligand Strands. Helv. Chim. Acta 1991, 74 (8), 1843-1852.

(52) Monchaud, D.; Jodry, J. J.; Pomeranc, D.; Heitz, V.; Chambron, J.-C.; Sauvage, J.-P.; Lacour, J. Ion-Pair-Mediated Asymmetric Synthesis of a Configurationally Stable Mononuclear Tris(diimine)Iron(II) Complex. Angew. Chem., Int. Ed. 2002, 41 (13), 2317-2319.

(53) Pomeranc, D.; Jouvenot, D.; Chambron, J.-C.; Collin, J.-P.; Heitz, V.; Sauvage, J.-P. Templated Synthesis of a Rotaxane with a [Ru(diimine)3]2+ Core. Chem. - Eur. J. 2003, 9 (17), 4247-4254.

(54) Boer, D. R.; Kerckhoffs, J. M. C. A.; Parajo, Y.; Pascu, M.; Usón, I.; Lincoln, P.; Hannon, M. J.; Coll, M. Self-Assembly of Functionalizable Two-Component 3D DNA Arrays through the Induced Formation of DNA Three-Way-Junction Branch Points by Supramolecular Cylinders. Angew. Chem., Int. Ed. 2010, 49 (13), 23362339.

(55) Oleksi, A.; Blanco, A. G.; Boer, R.; Usón, I.; Aymamí, J.; Rodger, A.; Hannon, M. J.; Coll, M. Molecular Recognition of a Three-Way DNA Junction by a Metallosupramolecular Helicate. Angew. Chem., Int. Ed. 2006, 45 (8), 1227-1231.

(56) Phongtongpasuk, S.; Paulus, S.; Schnabl, J.; Sigel, R. K. O.; Spingler, B.; Hannon, M. J.; Freisinger, E. Binding of a Designed AntiCancer Drug to the Central Cavity of an RNA Three-Way Junction. Angew. Chem., Int. Ed. 2013, 52 (44), 11513-11516.

(57) Wan, Q.; Xia, J.; Lu, W.; Yang, J.; Che, C.-M. Kinetically Controlled Self-Assembly of Phosphorescent AuIII Aggregates and Ligand-to-Metal-Metal Charge Transfer Excited State: A Combined Spectroscopic and DFT/TDDFT Study. J. Am. Chem. Soc. 2019, 141 (29), 11572-11582.

(58) Kung, K. K.; Ko, H. M.; Cui, J. F.; Chong, H. C.; Leung, Y. C.; Wong, M. K. Cyclometalated gold(III) complexes for chemoselective cysteine modification via ligand controlled C-S bond-forming reductive elimination. Chem. Commun. 2014, 50 (80), 11899-902.

(59) Maguire, C. M.; Rosslein, M.; Wick, P.; Prina-Mello, A. Characterisation of particles in solution - a perspective on light scattering and comparative technologies. Sci. Technol. Adv. Mater. 2018, 19 (1), 732-745.

(60) Zou, T.; Lum, C. T.; Chui, S. S.; Che, C. M. Gold(III) complexes containing N-heterocyclic carbene ligands: thiol "switch-on" fluorescent probes and anti-cancer agents. Angew. Chem., Int. Ed. 2013, 52 (10), 2930-3.

(61) Zhou, X. Q.; Busemann, A.; Meijer, M. S.; Siegler, M. A.; Bonnet, $S$. The two isomers of a cyclometallated palladium sensitizer show different photodynamic properties in cancer cells. Chem. Commun. 2019, 55 (32), 4695-4698.

(62) Karges, J.; Kuang, S.; Maschietto, F.; Blacque, O.; Ciofini, I.; Chao, H.; Gasser, G. Rationally designed ruthenium complexes for 1and 2-photon photodynamic therapy. Nat. Commun. 2020, 11 (1), 3262.

(63) Zhou, X. Q.; Xiao, M.; Ramu, V.; Hilgendorf, J.; Li, X.; Papadopoulou, P.; Siegler, M. A.; Kros, A.; Sun, W.; Bonnet, S. The SelfAssembly of a Cyclometalated Palladium Photosensitizer into ProteinStabilized Nanorods Triggers Drug Uptake In Vitro and In Vivo. J. Am. Chem. Soc. 2020, 142 (23), 10383-10399. 
(64) Huang, H.; Zhang, P.; Chen, H.; Ji, L.; Chao, H. Comparison Between Polypyridyl and Cyclometalated Ruthenium(II) Complexes: Anticancer Activities Against 2D and 3D Cancer Models. Chem. - Eur. J. 2015, 21 (2), 715-725.

(65) Gill, M. R.; Garcia-Lara, J.; Foster, S. J.; Smythe, C.; Battaglia, G.; Thomas, J. A. A ruthenium(II) polypyridyl complex for direct imaging of DNA structure in living cells. Nat. Chem. 2009, 1 (8), 662-7.

(66) Modica-Napolitano, J. S.; Aprille, J. R. Delocalized lipophilic cations selectively target the mitochondria of carcinoma cells. Adv. Drug Delivery Rev. 2001, 49 (1), 63-70.

(67) Madak, J.; Neamati, N. Membrane Permeable Lipophilic Cations as Mitochondrial Directing Groups. Curr. Top. Med. Chem. 2015, 15 (8), 745-766.

(68) Miyazono, Y.; Hirashima, S.; Ishihara, N.; Kusukawa, J.; Nakamura, K. I.; Ohta, K. Uncoupled mitochondria quickly shorten along their long axis to form indented spheroids, instead of rings, in a fission-independent manner. Sci. Rep. 2018, 8 (1), 350.

(69) Mazzei, L.; Wenzel, M. N.; Cianci, M.; Palombo, M.; Casini, A.; Ciurli, S. Inhibition Mechanism of Urease by $\mathrm{Au}(\mathrm{III})$ Compounds Unveiled by X-ray Diffraction Analysis. ACS Med. Chem. Lett. 2019, 10 (4), 564-570.

(70) de Almeida, A.; Mosca, A. F.; Wragg, D.; Wenzel, M.; Kavanagh, P.; Barone, G.; Leoni, S.; Soveral, G.; Casini, A. The mechanism of aquaporin inhibition by gold compounds elucidated by biophysical and computational methods. Chem. Commun. 2017, 53 (27), 3830-3833.

(71) Meanwell, M.; Nodwell, M. B.; Martin, R. E.; Britton, R. A Convenient Late-Stage Fluorination of Pyridylic C-H Bonds with NFluorobenzenesulfonimide. Angew. Chem., Int. Ed. 2016, 55 (42), 13244-13248.

(72) Du, L. P.; Tsai, K. C.; Li, M. Y.; You, Q. D.; Xia, L. The pharmacophore hypotheses of $\mathrm{I}(\mathrm{Kr})$ potassium channel blockers: novel class III antiarrhythmic agents. Bioorg. Med. Chem. Lett. 2004, 14 (18), 4771-7.

(73) Carvalho, J. F. S.; Louvel, J.; Doornbos, M. L. J.; Klaasse, E.; Yu, Z.; Brussee, J.; IJzerman, A. P. Strategies to reduce HERG K+ channel blockade. Exploring heteroaromaticity and rigidity in novel pyridine analogues of dofetilide. J. Med. Chem. 2013, 56 (7), 2828-40.

(74) Yu, Z.; van Veldhoven, J. P. D.; Louvel, J.; 't Hart, I. M. E.; Rook, M. B.; van der Heyden, M. A. G.; Heitman, L. H.; IJzerman, A. P. Structure-Affinity Relationships (SARs) and Structure-Kinetics Relationships (SKRs) of Kv11.1 Blockers. J. Med. Chem. 2015, 58 (15), 5916-29.

(75) Felipe, A.; Vicente, R.; Villalonga, N.; Roura-Ferrer, M.; Martinez-Marmol, R.; Sole, L.; Ferreres, J. C.; Condom, E. Potassium channels: new targets in cancer therapy. Cancer Detect. Prev. 2006, 30 (4), 375-85.

(76) Pardo, L. A.; Stuhmer, W. The roles of $\mathrm{K}(+)$ channels in cancer. Nat. Rev. Cancer 2014, 14 (1), 39-48.

(77) Feng, P.; Zhao, L.; Guo, F.; Zhang, B.; Fang, L.; Zhan, G.; Xu, X.; Fang, Q.; Liang, Z.; Li, B. The enhancement of cardiotoxicity that results from inhibiton of CYP 3A4 activity and hERG channel by berberine in combination with statins. Chem.-Biol. Interact. 2018, 293, $115-123$.

(78) Jeevaratnam, K.; Chadda, K. R.; Huang, C. L.; Camm, A. J. Cardiac Potassium Channels: Physiological Insights for Targeted Therapy. J. Cardiovasc. Pharmacol. Ther. 2018, 23 (2), 119-129.

(79) He, S.; Moutaoufik, M. T.; Islam, S.; Persad, A.; Wu, A.; Aly, K. A.; Fonge, H.; Babu, M.; Cayabyab, F. S. HERG channel and cancer: A mechanistic review of carcinogenic processes and therapeutic potential. Biochim. Biophys. Acta, Rev. Cancer 2020, 1873 (2), 188355.

(80) Yu, Z.; van Veldhoven, J. P.D.; 't Hart, I. M.E.; Kopf, A. H.; Heitman, L. H.; IJzerman, A. P. Synthesis and biological evaluation of negative allosteric modulators of the Kv11.1(hERG) channel. Eur. J. Med. Chem. 2015, 106, 50-59.

(81) Nakao, K.; Minato, N.; Uemoto, S. Innovative medicine: basic research and development; Springer Open: Tokyo, 2015.

(82) Ilari, A.; Baiocco, P.; Messori, L.; Fiorillo, A.; Boffi, A.; Gramiccia, M.; Di Muccio, T.; Colotti, G. A gold-containing drug against parasitic polyamine metabolism: the $\mathrm{X}$-ray structure of trypanothione reductase from Leishmania infantum in complex with auranofin reveals a dual mechanism of enzyme inhibition. Amino Acids 2012, 42 (2-3), 80311.

(83) Gukathasan, S.; Parkin, S.; Awuah, S. G. Cyclometalated Gold(III) Complexes Bearing DACH Ligands. Inorg. Chem. 2019, 58 (14), 9326-9340.

(84) Zeng, X.; Sun, J.; Li, S.; Shi, J.; Gao, H.; Sun Leong, W.; Wu, Y.; Li, M.; Liu, C.; Li, P.; Kong, J.; Wu, Y.-Z.; Nie, G.; Fu, Y.; Zhang, G. Blood-triggered generation of platinum nanoparticle functions as an anti-cancer agent. Nat. Commun. 2020, 11 (1), 567.

(85) Hopkins, S. L.; Siewert, B.; Askes, S. H.; Veldhuizen, P.; Zwier, R.; Heger, M.; Bonnet, S. An in vitro cell irradiation protocol for testing photopharmaceuticals and the effect of blue, green, and red light on human cancer cell lines. Photochem. Photobiol. Sci. 2016, 15 (5), 64453.

(86) Spek, A. L. Structure validation in chemical crystallography. Acta Crystallogr., Sect. D: Biol. Crystallogr. 2009, 65 (2), 148-55.

(87) te Velde, G.; Bickelhaupt, F. M.; Baerends, E. J.; Fonseca Guerra, C.; van Gisbergen, S. J. A.; Snijders, J. G.; Ziegler, T. Chemistry with ADF. J. Comput. Chem. 2001, 22 (9), 931-967.

(88) Vichai, V.; Kirtikara, K. Sulforhodamine B colorimetric assay for cytotoxicity screening. Nat. Protoc. 2006, 1 (3), 1112-1116.

(89) Zeman, S. M.; Crothers, D. M. Simultaneous measurement of binding constants and unwinding angles by gel electrophoresis. Methods Enzymol. 2001, 340, 51-68. 